九州大学学術情報リポジトリ

Kyushu University Institutional Repository

\title{
An Anatomical Study of The Leaves of The Genus Pinus
}

Doi, Tohe i

Kyushu Imperial University

Morikawa, Kin-ichi

Kyushu Imperial University

https://doi.org/10.5109/22553

出版情報：九州大学大学院農学研究院紀要. 2 (6)，pp. 149-198，1929-02. Kyushu Imperial University バージョン：

権利関係 : 
Journal of the Department of Agriculture, Kyushu Jmperial University, Vol. z, No. 6.

February 20, 1929

\section{AN ANATOMICAL STUDY OF THE LEAVES OF THE GENUS PINUS}

\section{Tōhei Dor and Kin-ichi MoRikawa}

\section{CONTENTS}

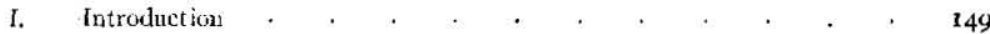

II. Fibro-vascular bundle . . . . . . . . . $15 \mathbf{I}$

III. Endoderm . . . . . . . . . $\$ 53$

IV. Resin canal . . . . . . . . . . . 157

V. Itypoderm . . . . . . . . . . . . . 1162

1. Epiderm and stonsita . . . . . . . . . 165

VII. The relation between the namral system of classification of the grenus
Tinus and the anatomical chatacters of leaves. . . . 160

VIIt. Analytical key to the species of the genus finus. hased an the anatomical characters of the leares. . . . . . . 168

IX. Literature cited . . . . . . . . . . $\quad$ I 83

X. Index to the species, varieties and their synonyus in the Analytical
Key (Chapter VIII) . . . . . . . . . SS

\section{INTRODUCTION}

So far as the natural system of classification of the species of the genus Pinns is concerned, it is most complete and we have a wide literatures on this subject.

We believe that the natural system of classification of the genus finus was systematized perfectly in A. LNGLer and K. PRANTL's "Die natürlichen Pflanzenfamilien 2-Aulage, I3-Band" published in 1926 (3). This represented a Inng step forward as compared with either their 
first edition (1889) or A. ENGLEk and E. GILG's "Syllabus der Pflanzenfamilien 9 und 10-Auflage (1924)," and especially it takes into consideration the anatomical characters of the leaves as the basis of classification as Koenne (5), Masier (10) and Shaw (14) had already attempted to do.

We, therefore, considered what elements of the anatomical characters of the pine leaves would be most important to the new natural system of classification of A. ENGLER and K. Prantl (3). And beginning with those elements which have the closest connection with a natural system of classification, and proceeding to those of less vital relation, we have worked to cstablish a practical artificial system of classification of the genus Pinus, which shall correspond as closed as possible to the natural system of classification.

The anatonical characters of the leaves used for this purpose show in each species some one definite peculiarity and these characters, such as are indicated below, are easily distinguishable in a transverse section of a leaf :-

I. Whether the fibro-vascular bundle is single or double.

2. Are there in the stelar tissue surrounding the fibro-vascular bundle the sclerenchyma strengthing cells, which show the chemical reaction of hypoderm cells? If so, what degree of development do they show?

3. The shape of the endoderm.

4. (a). Are the walls of the endoderm-cells uniform or otherwise?

(b). Are the outer walls thick, or not?

(c). Are there both thick and thin outer walled cells?

5. Are the cndoderm-cells of equal, or very unequal size, some of them large?

6. The position, number and sometimes the size of the resin canals.

7. Are the cells which surround the resin canal thin or thick walled?

8. When resin canals are situated close to the hypoderm, do the sclerenchyma cells, which encircle the resin canal, surround it perfectly on all its circumference? Are they wanting in the part touching the hypoderm?

9. The legree of development of the hypoderm.

10. The thickness of the epiderm, and the situation, sometimes the number of the stomata. 
But it must be considered as an inevitable consequence of the artificial classification that there are a few points inconsistent with the natural system of classification (3).

For the arrangement of Subgenus, Section and Subsection etc. of the natural system of classification we are indebted to A. Fxgicer and K. l'RANL (3), but in regard to the scientific names, there are not a few we owe to other botanists.

Since the anatomical characters formed in a transverse section taken from the middle part of leaf shows most clearly the characteristic structure of a given species (12, 15 ), the species were distinguished on the basis of such transverse sections.

In the case of species for which green leaves were not avalable, a section of about $2 \mathrm{~cm}$. in length was cut fiom the middle part of withered leaves of dried specimens. And after expelling the air from the dried leaves by boiling, they were put to soak in a mixture of equal parts of glycerin and aether for from 6 months to one year, after which the leaves became normally expanded. Then they were made into transverse sections for the examination.

Concerning the number of the species of the genus Pinus the botanists have many different opinions. A. ENGLER and K. PRANTL (3) say there are 80-90 species. However, while accepting the conclusions of other students, we have made some corrections in the species.

$T$. Dor collected the leaves of most of the species of the genus pimus. K. Morukawa has been collecting the leaves of the remaining species and has made a comparative examination of the anatomical characters of various kind of leaves and has distinguished all species as much as possible.

We must be very much obliged to Prof. Dr. R. Kanfhira, Prof. 1)r. M. Fujioka of the Department of Agriculture of Tokyo University, and Prof. Dr. S. KaWagoe of the Agricultural and Forestry College Kagoshima for their useful books of reference and precious materials.

\section{FIBRO-VASCULAR BUNIDLE:}

It is already known that the fibro-vascular bundle which runs through the leaf is single in Soft Pine and constantly or irregularly double in Hard Pine $(2,3,4,5,10,11,13,14,15)$. This distinction is employed by Koense (5) as the basis of his two Sections, Haploxylon and Diploxylon. 
Shaw (r 4) has accordingly divided the genus Pinus into two main Sections, Haploxylon and Diploxylon, and further into Subsections or Groups.

And also in the new natural system of classification A. ENGLer and K. PRANiL (3) have divided it into "Untergattung I. Haploxylon Koeine" and "Untergattung II. Diploxylon Koenne" and further into "Sektion" or "Untersektion" etc. .

Thus the fibro-vascular bundle has been regarded as a more important basis for the classification of Pinus than the fowers, cones, seeds etc. The double bundles are usually obvious even when they are contiguous, but they are sometimes completely merged into what appears to be a single bundle. This condition, however, is never constant in Hard Pine, and a little investigation will find a leaf with true double bundles.

In the stelar tissue some cells about the fibro-vascular bundle acquire thick walls with the appearance and chemical reaction of hypoderm cells (5, I I, I2, I3, I4). Among the Haploxylon this condition is most obvious in Pinus monoflyylla, $P$. cembroides, $P$. edulis, $P$. quadrifolia, $P$. flexilis, $P$. parifitora, $P$. pentaphylla, $P$. Balfouriana and $P$. formosana. Among the Diploxylon it appears in all degrees of development. The Diploxylon, therefore, falls under the following ive cases according to the sclerenchyma cells in the stelar tissue :-

1. deficient. (P. radiata etc.)

2. Several sclerenchyma cells lie scattered below the fibro-vascular bundles, often below and above. (Fig. I-A) (P. Massoniana etc.)

3. Sclerenchyma cells form an irregular line below the fibrovascular bundles, occasionally several of them lie scattered above the bundles. (Fig. I-B) (P. densiflora, P. montana, P. palustris, $P$. silvestris, $P$. Thunbergii etc.)

4. Sclerenchyma cells form irregular lines below and above the fibro-vascular bundles. (Fig. I-C) ( $P$. Montezumae, P. oocarpa, P. Torreyana etc.)

5. Scicrenchyma cells not only form irregular lines below and above the fibro-vascular bundles, but also lie scattered between the two bundles forming "I" shape. (Fig. I-D) ( $P$. occidentalis, P. Sabiniana, P. tropicalis etc) 

A
B
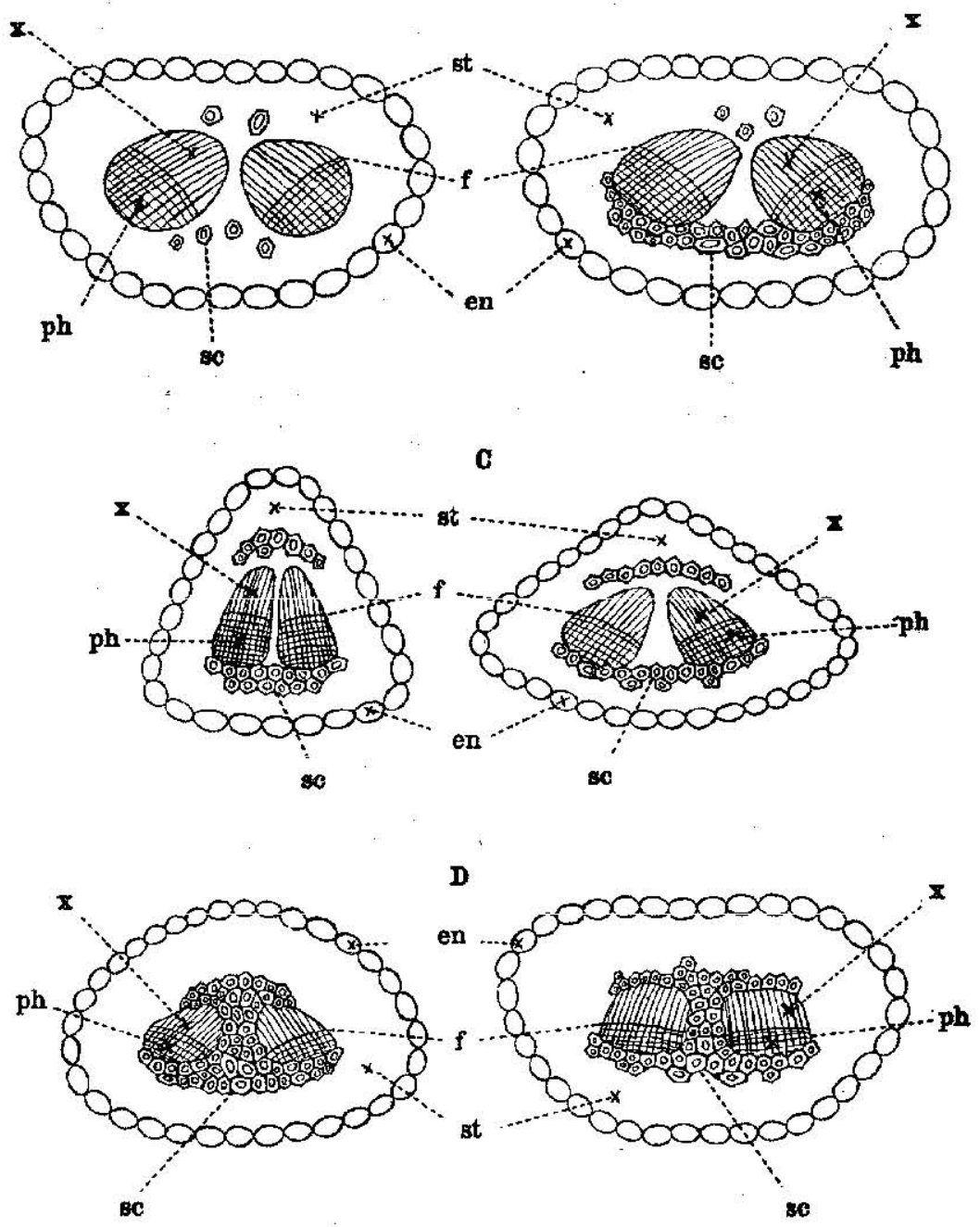

Fig. x. Sclerenchyma cells about the fibro-vascular bundle. en=endoderm, $s t \Rightarrow s t e l a r$ tissue, $f=$ fibro-vascular bundle, $x=x y l e m, p^{h}=p h$ loem, $s c=$ sclerenchyma cells.

\section{ENDODERM}

Endoderm is the boundary tissue between the stelar tissue surrounding the fibro-vascular bundle and the green tissue, and its shape 
is of the greatest importance in the classification of the species. Its shape can not be descidcal only by the shape of the transverse section of a leaf, for among the Diploxylon it varies much according as the space between two fibro-vascular bundles is wide, contiguous or approxinately merged into one. The endoderm of the species with 5 leaves in fascicles among the IAploxylon is always circular in shape, but those among the Diploxylon are triangular. It is short-based triangular even in such a species as have 6 to 8 leaves in fascicles, since they belong to the Diploxylon. In the species with 3 leaves in fascicles it is circular or broacl-elliptical in the Haploxylon, but in the Diploxylon long-based triangular or elliptical. In the species with 2 leaves in fascicles, however, it is elliptical in the Haploxylon such as $P$. edutis as in the Diploxylon. Only in such species as $P$. Banksiana, $P$. contorta, $P$. silvestris is it strangled-cocoon-like in shape.

The following classifications were worked out on the basis of the shape of the endoderm.

I. Haploxylon.

I. Endoderm circular. (Fig. 2- $\Lambda$ ).

All species of the Haploxylon except $P$. edulis. All species belonging to the following group (2), excepting the species $P$. edulis, were changed to both case (I) and case (2).

2. Endoderm broad-elliptical. (Fig. 2-B).

$P$. Bungeana, $P$. cembroides, $P$. cidulis, $P$. (ierardiana, P. monoplyylla, P. Nelsonii, P. Pinceana.

II. Diploxylon.

3. Endoderm triangulas.

(a) Fondodern short-based triangular. (Fig. 2-c).

P. Montezumae, P. Montesmat var. Lindleyi, P. Montezumae iar. rudis.

(b) Lindoderm regular-triangular. (Fig. 2-1)).

P. arizonica, I'. leiophylla, I'. MTontesumae, I'. Montezunac

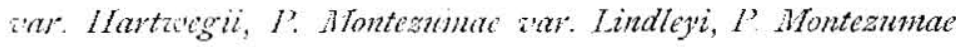
atar rudis, $P$. occidentalis, $P$. ovcarpa, I' pseudostrobus, $P$. picudostrobus war. tenuifolia, $P$. teocote, 1 . Torreyana.

(c) Enduderm long-based triangular. (Fig. 2-1).

P. attenuata, $P$. canariensis, P. caribaea, P. chiluathuana, $P$. Conlteri, P. echinate, P. Engelmannii, P. Gregii, P. insularis, 

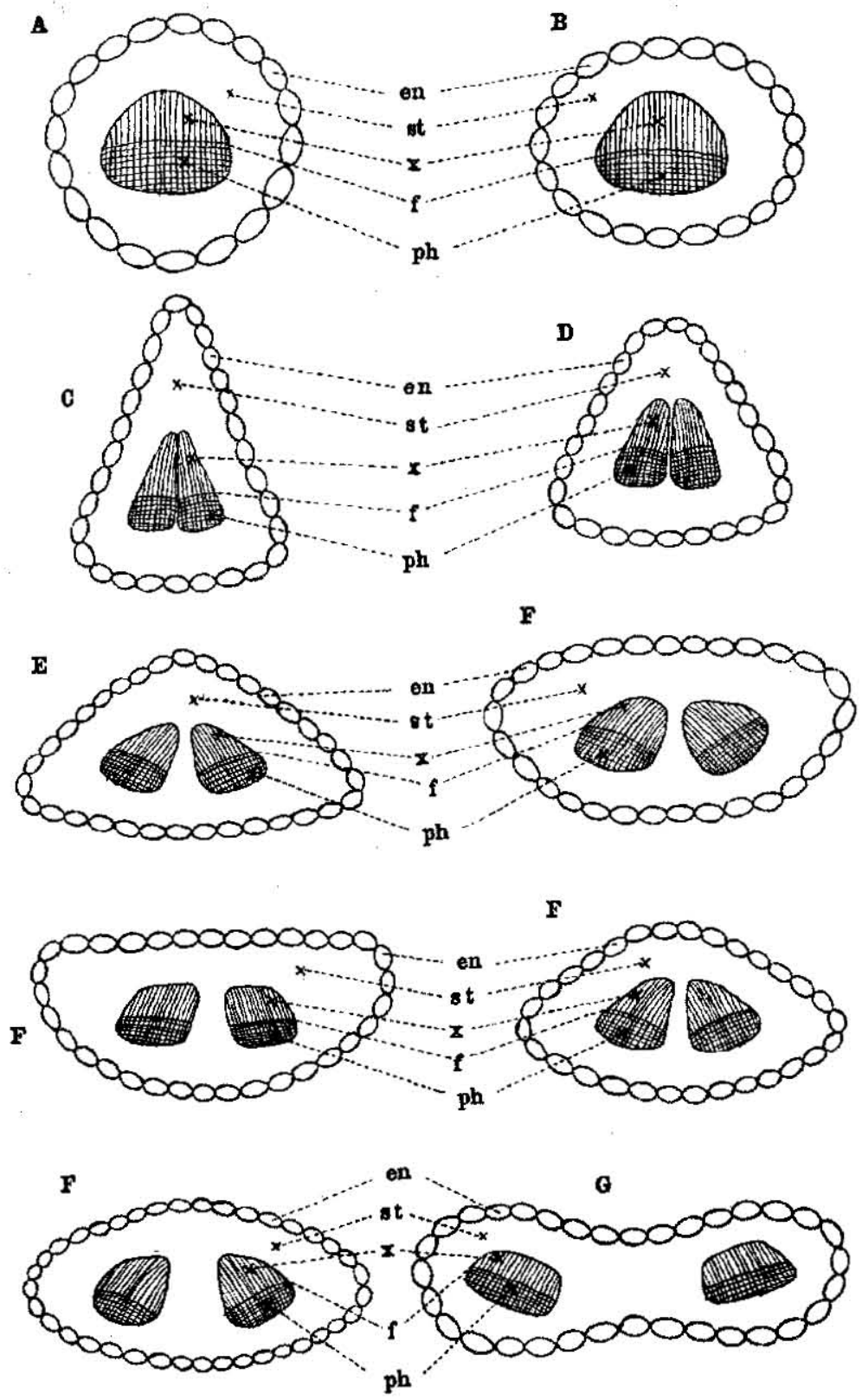

Fig. 2. Shape of the endoderm. A=circular, $\mathrm{B}=$ broad.elliptical, $\mathrm{C}=$ short-based triangular, $\mathrm{D}=$ regular-triangular, $\mathrm{E}=$ long-based triangular, $\mathrm{F}=$ elliptical, $\mathrm{G}=$ strangled $\mathrm{cocon}$ like. $e n=$ endnderm, st $=$ stelar tissue, $\mathrm{f}=$ fibro-vascular bundle, $\mathrm{x}=\mathrm{xylem}, \mathrm{ph}=$ phloem. 
P. Jeffreyi, P. longifolia, P. Lazusonii, P. Lumholtzii, P. Montezumae, I?. Montezunat var. Hartwegii, P. Montezumae var. Linalcyi, $P$. oocurpa, $P$. palustris, $P$. patula, $P$. ponderosa, $P$. Pringlei, $P$. radiata, $P$. rigida, $P$. Sabiniana, $P$. serotina, P. taeda, $P$. teocote.

4. Endoderm elliptical. (Fig. 2-F).

$P$. attenuata, P. brevispica, $P$. canariensis, $P$. caribaea, $P$. chihuahuana, $P$. clausa, $P$. Conlteri, $P$. densiflora, $P$. densiftora $\mathrm{X} P$. Thunbergii, $P$. Thunbergii X $P$. densiflora, P. echinata, P. Engelmannii, $P$. glabra, P. Gregii, $P$. halepensis, $P$. insularis, $P$. Jeffreyi, $P$. Lawsonit, $P$. leucodernis, $P$. longifolia, $P$. luchuensis, P. Lumholtaii, P. Massoniana, P. Merkusii, P. montana, P. muricata, $P$. nigra, $P$. occidentelis, $P$. palustris, $P$. patula, $P$. pinaster, P. pinea, P. ponderosa, P. Pringlei, P. pungens, $P$. radiata, I'. resinosa, P. rigida, I'. Sabiniana, P. serotina, $P$. tabulacformis, 1 '. taeda, $P$. taiwantusis, $P$, teocote, $P$. Thunbergii, 1. tropicalis, P. virginiana.

5. Endoderm strangled-cocoon like. (Fig. 2-(i).

P. Banksiana, P. contorta, P. silvestris.

It has been admitted that in many species the walls of the endodermcells are uniform, but in some specics the outer walls of the endodermcells are conspicuously thick (10, I3, 14. I5) and in others the endoderm-cells are very unçual in size, some being large and some small (14).

Supplemented with the results of our observation, the characters of the enclodern are as follows:-

I. Hindoderm-cells are approximately equal in their size and have walls of uniform thickness. (Fig. 3-A).

Most species of Pinus.

2. The outer walls of the endorlerm-cells are conspicuously thick. (Fig. 3-в).

P. albicaulis, I'. Banksiana, P. contorti, I'. Montezunac, $P$. ponderosa, P. teocote, etc.

3. Encloderm-cells with both thick and thin outer walls. (Fig. 3-c). $P$. Coulteri, P. longifolia, P. Torreyana, etc.

4. Endoderm-cells are very unequal in size, some being large and some small. (Fig. 3-D).

P. Merkusii. 
A
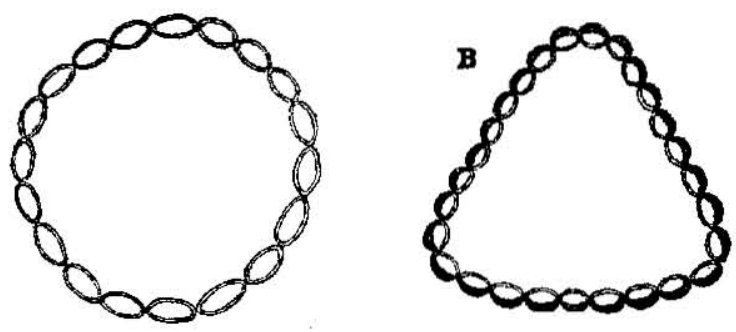

D
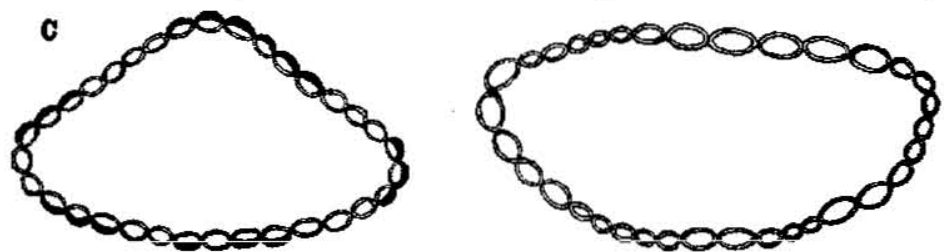

Fig. 3. Characters of the endoderm-cells.

IV. RESIN CANAT,

The positions of resin canals can be divided into four types as follows; namely, (I) close to the cncloderm, i.e. internal; (2) in the green tissue between the endoderm and hypoderm, i.e medial; (3) close to the hypoderm, i.c. external; (4) across the green tissue, touching both the endoderm and hypoderm, i.e. septal. One of these positions is constant or any two of thesc are combined in the same spccies. So various are the positions of resin canals according to species. And along with the fibro-vascular bundie, the position of the resin canal is the most characteristic among the anatomical characters of a leaf. Thus many botanists of the past employed these positions in the leaves as the basis of the natural system of classification $(1,2,3$, $5,7,10,11,13,14,15)$.

The number of resin canals of a leaf is variable or constant according to the species, and this also aided us much in the classification of species $(1,7,15)$. In such species as $P$. aristata, $I$. Neisonii and $P$. pumila, there are generally two resin canais, rarely only one, but in the other species there are always more than two.

As a rule, the species which are always constant in the number of resin canals in a leaf have only two or three resin canals. But it must be admitted that there are a few exceptional case. Species such as $P$. Banksiana, $P$. cembra, $P$. contorta, $P$. strobus, $P$. Torreyana, etc. all 
belong to this type. The specics, which have more than four resin canals, are always variable in the number of their resin canals. In many species the number of resin canals in a leaf varies from two to cight, and rarely from two to fifteen, in such species as $P$. densiflora, $P$. nigra, $P$. pinaster, $P$. silvestris, $P$. Thunbergii, etc. .

Either in the Haploxylon or in the Diploxylon, the cells surrounding and protecting the resin canals are different according to the species. Some of them are thin-walled cells and others are thick-walled, and shiny white in appearance.

Concerning the sclerenchyma cells surrounding and protecting the resin canals, the following seven types have bcen observed:-

I. Both the cells surrounding the resin canals and the hypoderm cells are thin-walled and weak. P. albicaulis, $P$. Bungeana, $P$. koraiensis, $P$. monticola, P. parviflora, etc.

2. The cells surrounding the resin canals are thin-wallect, but the hypoderm cells arc thick-walled. $P$. contorta, $P$. palustris, $P$. Torreyana, etc.

3. The cells surrounding the resin canals are thick-walled, but the hypoderm cells are thin-walled. I'. densiflora, P. Massoniana, $P$. silvestris, etc.

4. Both the cells surrounding the resin canals and the hypoderm cells are thick-walled. P. monophylla, $P$. nigra, $P$. Thunbergii, etc.

5. Resin canals lie externally, and the sclerenchyma cells surrounding them are continuous. (Fig. 4-J) P. Balfouriana, P. monticola, $P$. silvestris, etc.

6. Resin canals lie externally, and the sclerenchyma ceils surrounding them are wanting at the point touching the hypoderm and 2 to 4 secreting cells are close to the hypoderm. (Fig. $4-\mathrm{K}$ ) $P$. densiftora, $P$. Massoniana, $P$. quadrifolia, etc.

7. Resin canals lie externally, and the sclerenchyma cells surrounding them are continuous and surround the total circumference of some canals, but about others they are wanting at the parts touching the hypoderm, and secreting cells arc close to the hypoderm. (Fig. 4-J, k) I'. densiftora X I. Thunbergii, $P$. Thunbergii $\mathrm{X} P$. densiflora, $P$. tabulaeformis.

Resin canals which lie externally are buried in the hypoderm, in which case they are very small ( $P$. Nelsonii etc.). But the canals of 
some species arc so large that they touch both the endoderm and the hypoderm and thus form a septum ( 1 . tropicalis).

In the case of the species in which the number of resin canals in a leaf is constantly two or three, the canals are almost the same in size; but in the case the many species in which the number of resin canals is variable, large and small canals are mixed $(P$. densiflora, $P$. echinata, P. nigra, $P$. silvestris, P. Thunbergii, etc.).

The following classifications were worked out on the basis of the positions of resin canals :-

I. Haploxylon.

I. Resin canals medial, i.e. situated in the green tissue, touching neither the endoderm nor hypoderm. (Fig. $4^{-G}$ ).

P. cembra, $P$. koraiensis.

2. Resin canals medial and external, i.e. some of the resin canals in the green tissue, but some of them touching the hypoderm.

(Fig. 4-H).

P. Armandi, 1. Lambertiana.

3. Resin canals external, i.e. situated close to the hypoderm. (Fig. 4-1).

P. albicaulis, $P$. anamiana, $P$. aristata, P. ayacahuite, $P$. Balfouriana, $P$. Bungeana, $P$. cembroides, $P$. edulis, $P$ excelsa, $P$. flexilis, P. formosana, $P$. Gerardiana, P. Lambertiana, $P$. monophylla, I'. monticola, P. Nelsonii, P. parviflora, P. pentaphylla, P. peuce, P. Pinceana, P. pumila, P. quadrifolia, P. strobus, P. Uyematsui.

II. Diploxylon.

1. Resin canals internal, i.e. situated close to the encluderm. (Fig. 4-A).

P. caribaca, P. Lawsonii, P. occidentalis, P. palustris, P. Pringlei.

2. Resin canals internal and medial, i.e. some of the resin canals touching the endoderm, but others in the green tissue. (Fig. $4-5)$.

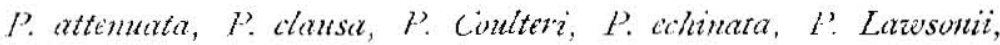
P. leiophylla, P. Lumholtzii, P. Merkusii, P. patula, P. pungens, P. radiata, $P$. rigida, $P$. scrotina, $I$. taeda, $P$. tcocote, $P$. virsiniane.

3. Resin canals internal and septal, i.e. some of resin canals touching the endoderm, but others touching both the endoderm and hypoderm, forming a septum. (Fig. 4-C). 

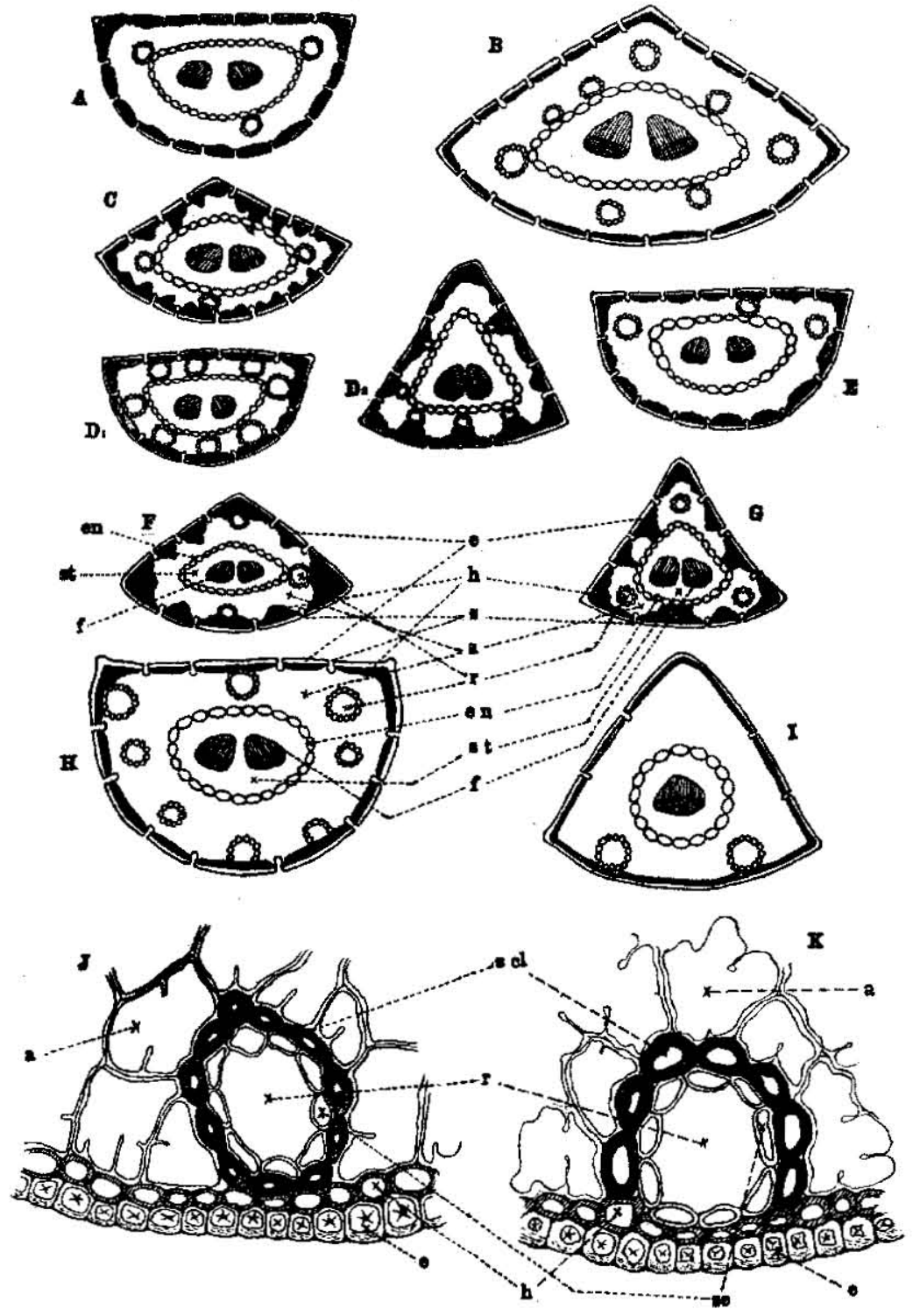

Fig. 4. Positions of the resin canals. A=internal, $B=$ internal and medial, $C=$ internal and septal, $D_{1}=D_{2}=$ septal, $F=$ septal and medial, $F=$ septal and technically cxternal, $\mathrm{G}=$ medial, $\mathrm{H}=$ medial and external, $\mathrm{J}=$ external, $\mathrm{J}=$ resin canals jic externally, and the sclerenchyma cells surrounding them are continuous, $\mathrm{K}=$ resin canals lie externally, and the scierenchyma cells surnunding them are wanting at the point truching the hypoderm and 2 to 4 secreting cells are close $t$, the hypoderin. $e=$ epiderm, $s=$ stomat $a, h=h y p$ ierm, $a=a s-$ similative tissue (green tissue), $r=$ resin canal, en=endoderm, st $=$ stelar tissue, $f=$ fibro-yascular bundle, $" \mathrm{scl}=$ sclerenchyma cells surrounding the resin canal, se $=$ secreting cells. 


\section{P. oocarpa, $P$. Pringlei.}

4. Resin canals septal, i.e. situated close to both the endoderm and hypoderm, forming a scptum. (Fig. $4-D_{1}, D_{2}$ ).

P. oocarpa, $P$. tropicalis.

5. Resin canals septal and medial, i.e. some of the resin canals touching both the endoderm and hypoderm, forming a septum, but others in the green tissue, touching neither the endoderm nor hypoderm. (Fig. 4-E).

P. Merkusii.

6. Resin canals septal and technically external, i.e. some of the resin canals touching both the endoderm and hypoderm, forming a septum, but others situated close to a remarkably developed hypoderm. (Fig. 4-F).

$P$. canariensis, $P$. tropicalis.

7. Resin canals medial, i.e. situated in the green tissue. (Fig. 4-G). $P$. arizonica, $P$. attenuata, $P$. Banksiana, $P$. brevispica, $P$. chihuahuana, P. clausa, P. contorta, P. Coulteri, P. echinata, $P$. Engelmannii, $P$. glabra, $P$. Gregii, $P$ Jeffreyi, $P$. leiophylla, L. leucodermis, $P$. luchuensis, $P$. Merkusii, $P$. Montezumae, $P$. Montezumae var. Hartwegii, P. Montezumat var. Lindieyi, P. Montezumae var. rudis, $P$. muricata, I: nigra, $P$. patula, $P$. pincrster, $P$ ponderosa, $P$. pseudostrobus, P. pseudostrobus var. tenuifolia, $P$. pungens, $P$. radiata, $P$ rigida, $P$. Sabiniana, $P$. serotina, P. taeda, P. taizonensis, $P$. teocote, P. Thunbergii, $P$. Torreyana, $P$. virginiana.

x. Recin canals medial and external, i.e. some of resin canals in the grcen tissue, but others touching the hypoderm. (Fig. 4-H) P. brevisfica, ${ }^{2}$. densiflora $\mathrm{X} P$. Thunbergii, P. Thunbergii $\mathrm{X}$ $P$. densiftora, $P$. insularis, $P$. luchu'nsis, P' resinosa, P' silvestris, P. taiwanensis.

9. Resin canals external, i.e. situated chose to the hypoderm. (Fig. 4-1).

P. canariensis, I'. densiflora, I'. hatepensis, P. insularis, P'. long ifolia, P. Massoniana, P. montana, P. pinea, P. resinosa, P. siliestris, P. tabulaeformis, $P$. tropicalis.

As illustrated above, some species are constant in the position of resin canals in all their leaves, and others are variable in the number or the position in their various leaves. Some species, especially such 
as $P$. attenuata, $P$. rigida, $P$. teocote, etc. have the resin canals medial, or medial and internal; and again there are a great number of species, such as $P$. insularis, $P$. Lambertiana, $P$. Iuchuensis, $P$. resinosa, $P$. taimanensis, etc., which have the resin canals medial, medial and extemal, or external.

\section{HYPODERM}

Among the Haploxylon there are many species which show a very weak hypoderm. But among Diploxylon a very different tendency is manifest. That is to say, many species anong the Haploxylon have but one layer of hypodemi cell, and are thin-walled and inconspicuous. But a few species show two or three layers of cells.

However, among the Diploxylon there are wide variations, so that while in some species the hypoderm is very weak and inconspicuous, others have one layer, two or three layers, and in some species five to seven layers, while the hypoderm pushes its way into the green tissue. One outstanding instance was where the hypoderm was so much developed; as to cross the green tissue and touch the endoderm, forming a septum.

In these varying forms of hypoderm, there were those with thin cell walls, and yet others with very thick walls of silvery which contrasted remarkably with the green tissue. $(2,4,8,10,1 \mathrm{I}, 13,14,15)$.

By Sinaw's study (14), as well as by the observations of the present authors, it is possible to classify the species according to the structure of the hypoderm.

I. Haploxylon.

I. Hypoderm consisting of one layer of thin-walled, inconspicuous cells. (Fig. 5-A).

$P$. albicaulis, $P$. cembra, $P$. koraiensis, $P$. partiflora, $P$. strobus, etc.

2. Hypoderm, some parts consisting of one layer of thin-walled cells and others of two layers. (Fig. 5-A).

P. monticola.

3. Hypoderm, some parts consisting of one layer of thick-walled cells, and others of two layers. (Fig. 5-B).

P. flexilis.

4. Hypoderm consisting of 2 or 3 layers of thick-walled cells. (Fig. 5-1). P. aristata, P. cembrcides, P. Lambertiana, etc. 

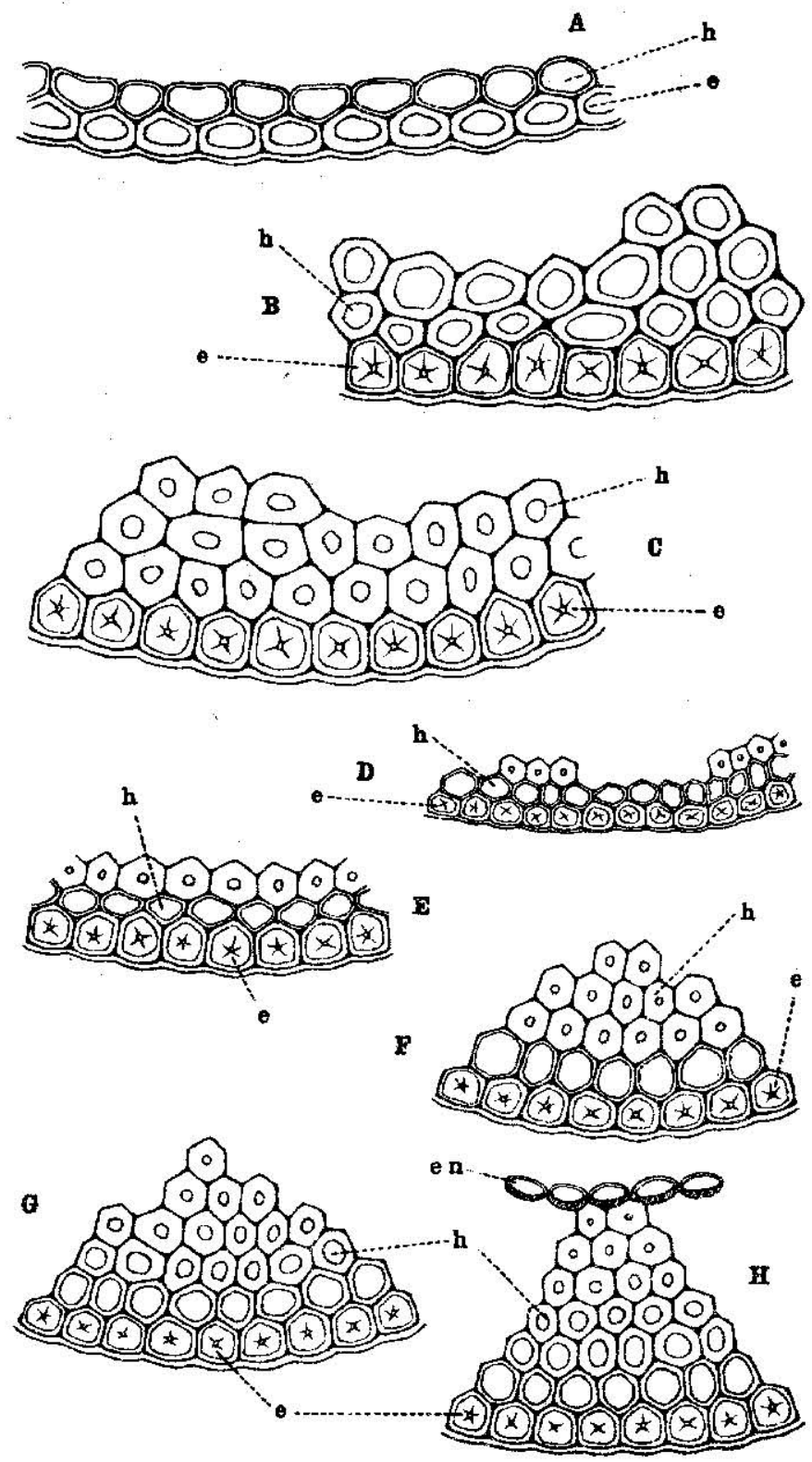

Fis. 5. Structure of the hypoderm. $A=B=C=$ uniform, $D=F=F=$ iform, $\quad:=H-$ nuitiform. e exiderm, $\mathrm{h}=$ hypoderm, en=endoderm. 
5. Hypoderm consisting of 2 or 3 layers of strong, thick-walled cells of shiny white color. (Fig. 5-c).

P. Balfouriana, $P$. monophylla.

II. Diploxylon.

1. Hypoderm of uniform thin-walled cells. (Fig. 5-A).

(a) Hypoderm consisting of one layer of thin-walled cells, occasionally having parts which consist of two layers of cells.

$P$. densiflora, P. Lumhoitzii, P. patula, P. silvestris, P. taiwanensis, etc.

(b) Hypoderm consisting of 2 or 3 layers of thin-walled cells. P. Gregii.

2. Hypoderm of uniform thick-walled cells. (Fig. 5-B).

(a) Hypoderm consisting of 2 or 3 layers of cells. P. halepensis, P. Merkusii, P. nigra, P. Thunbergï, P. tropicalis, etc.

(b) Hypoderm in large masses, projecting far in to the green tissue.

P. canariensis, P. longifolia, P. Torreyana, etc. (Fig. $5^{-c,}, \mathrm{G}$ ).

(c) Hypoderm remarkably developed, extending from the epiderm to the endoderm and forming a septum across the green tissue (Fig. 5 -C, H).

P. psendostrobus var. temifolia.

3. Ilipoderm biform, i.c. very thin walls situated in the outer layer of cells and very thick walls in the inner layer or layers of cells.

(a) Hypoderm, some parts consisting of onc layer of cells and others of two layers, biform in the parts of two layers of cells. (Fig. 5-1)).

P. clausa, I'. echinata, P. glabra, etc.

(b) Hypoderm consisting of 2 or 3 layers of cells. (Fig. 5-E).

$P$. contorta, P. palustris, P. pungens, P. radiata, P. taeda, ctc.

(c) Hypocierm in large masses, projecting far into the green tissuc and sometimes touching the entoderm. (Fig. 5-F).

P. Pringici.

4. Hypoderm multiform, i e. cell walls being gradually thicker toward the centre of the leaf. 
(a) Hypoderm projecting far in to the green tissue, but not extending to the endoderm. (Fig. 5-G).

I. Coulteri, I'. Montizunte', I' oocarfo, I'. fincster, 'P. ponderosa, ctc.

(b) Hypoderm remarkably developed, extending from the epiclem to the endoderm and forming a septum across the green tissue. (Fig. 5-11).

I'. pseudostrobus i'tr. tenuifolia.

There are the following four types in the casc where either the hypoderm or the connected tissue of the resin canal and the hypodem forms a septum across the green tissue.

I. Hypoderm extending from the epiderm to the endociem independently of the resin canal and forming a septum across the green tissue, owing to its won revelopment. (Fig. 4-G).

1. pseudostrobus arar. temifolia.

2. The septums are formed of remarkably large resin canals and a hypoderm which consists of only two or three layers of cells. (Fig. $4^{-n_{\mathrm{r}}}, \mathrm{r}$ ).

I. tropicalis.

3. Notwithstanding that resin canal is smail, a distinct septum is formed across the green tistue owing to the considerable development of the hypodcrn. (Fig. $4-\mathrm{D}_{2}, 1$ ).

I?. oocarpa.

4. In a sance leaf, the septums are fomed by the hypoterm only at some paits, ank by the coninected tissue of the hypoden and the resin canal at other parts. (Fig. 4-C)

P. Pringlei.

\section{EPIDERM AND STOMATA}

The cpiderm of the Haploxylon is very thin, while that of the Diploxylon is senerally thicker. But in each of these two Subgenus (I Iaploxylon and Diploxylon), the many species have approximately the same thickness, so that the epiderm is of small value for classification. I Iowever I'. contorta, I'. luchuthis and $P$. montang have a marked thickness of the epiderm.

In the Haploxylon there are two groups of species, one with stomata on the ventral side only, and the other with stomata on both the ventral and dorsal sides (1, 2, 4, 8, 10, 11, 13, 14, 15). 
Although fundamentally, the Haploxylon is poor in variations as compared with the Diploxylon, the fact that in stomata only the Haploxylon shows great variation is of value in classilication, for even in the Diploxylon species with 5 leaves in fascicies the stomata are always found on both dorsal and ventral sicks. Further our attention was drawn to the unusual size and visibility of the stumata in $P$. albicaulis and $P$. luchuensis.

The following classifications were worked out on the basis of the position and the number of the stomata.

I. Hapluxylon.

1. Stomata lie on the ventral sicle only.

Most species except group (2). I'ut P. centhroiles, P. monticola and $P$. Pinceanc are cccasionally included in this group.

2. Stomata lie on both dorsal and ventral sides.

(a) Stomata on the ventral side is only cne. $I$. Nelsomiz.

(b) Stomata on the ventral sicie are 3 to 6 in number.

P. albicaulis, P. Bungeana, $P$. cembroides, $P$. celulis, $P$. flexilis, P. Gerardiana, $P$. Iambertiana, $P$. monoplylla, $P$. monticala, $P$. Pinceana.

II. Diploxylon.

Stomata lie on both dorsal and ventral sicles.

VII. THE RELATION BETWEEN TILE NATURAL SYSTEM OF CLASSIFICATION OF THE GENUS PINCS AND THE ANATOMICAL CHARACTELS OF LEAVES

The authors have worked out a practical system of classifcation of the specics of Pinus on the basis of the anatomical characteristics of leaves. But our thought was to determine what elements of the anatomical characters of leaves have the most vital relation to a natural system of classification; and beginning with those elements which have the most vital relation to the natural system of clissification, and proceeding to those of less intimate relation; wo have worked to establish a most easy and practical system of classification of the gonus Pinus, which shatl correspond as closly as possible to the natural system of classification.

For this purpose, the authors have distinguished Subgenus, Section and Subsection divisions of Pins in tlie ncw natural systen of classification of A. ENGLER and K. PRANTL (3) on the basis of the anatomical characters of pine leaves. 
(A) Subgenus I. Haplorylon KowHNE

Fibro-vascular bundle single.

(a) Section 1. Combra Sracr

(a) Résin canals nedial.

(9) Resin canals mediat and extemal.

(y) Resin canals external, stmata on buth dorsal and ventral sides, cndoderm circular. (exccpt /'. punila).

(b) Section 2. Strobus Swrexl ex Spach

Resin canals mostly extcrnal, stumata on the ventral side only, hypoderm cells thin-walled and inconspictsons. (except $f$. Lambertiana).

(c) Section 3. Paracombra Koenns:

(a) Subsection 1. Cerardianat.

Resin canals external, stomata on both dorsal and ventral sides, endodem broad-elliptical. (except t'. quadrifolia).

(3) Subsection 2. Balfourianae.

Resin canals external, stomata on the ventral side only, hypoderm cells thick-walled and shiny white.

(B) Subgenus II. Diploxylon Kofluns

Fibro-vascular bundles double.

(d) Section 4. Sula Mayk

Resin canals technically external, enduderm triangular, hypoderm in large masses, projecting $f_{a r}$ in to the green tissue.

(e) Section 5. Fapitys SPacH

(a) Resin canals external, endoderm ellipticial, number of resin canal 2 to 8 , often to 15 .

(3) Resin canals nedial, endoderm cliptical, hypoderm uniform thick-walled cells.

(f) Section 6. Banksia Mark

Resin canals medial, rarely medial and internal, endoderm elliptical, hypoderm mostly biform.

(g) Section $\%$. Pinea Fint.

Resin canals external, endoderm elliptical, number of resin canal usually two.

(ii) Section 8. Szestrales PlLGir Resin canals intemal, sometimes intcmal and modial, cndoderm mustly triangular, hypocterm biform.

(i) Section 9. Khasia MaYr 
Resin canals external, rarely external and medial, endoderm triangular, hypoderm not projecting far in to the grcen tissue.

(j) Section 10. Pseudostrobus ENDL.

Resin canals medial, rarely medial and internal, endodem triangular, hypodcrm mostly in large masses, projecting far in to the green tiscue, outer walls of the endoderm mostly thick.

(k) Section I1. Taeda Spach

Resin canals medial, rarely medial and internal, endoderm triangular, hypodem not projecting far in to the green tissue, outer walls of the endoderm mostly thin.

It will be seen from the above that the most important point to the natural system of classification is whether the fibro-vascular bundle is single or double $(3,5,10,14,15)$. Then comc, among the Haploxylon, in the order of their importance, the position of the resin canal and stomata, the shape of the endoderm and the degree of development of the hypoderm, and among the I)jploxylon the position of the resin canal, the shape of the endoclem, the degree of development of the hypoderm, the number of the resin canals and the characters of the endodern-cells.

Hence if we classify the species, on the basis of the anatomical characters of leaves, in the order above, (also considering many additional points), the practical artificial system of classification would come close to the natural system.

And such the Practical Analytical Key to the Species of the Genus Pints is mentioned in the following Chapter VIII.

Resin canals of most species are external among the Haploxylon, but the position of the stomata is variable. This helps us much to classify the species. Among the Diploxylon, on the other hand, all stomata are situated on both dorsal and ventral sides. But the shape of the entoderm and the structure of the hypoderm have in each species some one definite peculiarity. We can, therefore, classify the species of the Diploxylon.

VIIT. ANALYTICAL KEY TO TIE SPECIES OF THE GENLS I'INUS, BASED ON THE ANATOMICAL CHARACTERS OF I.EAVES

(The figure in parenthesis following the scientific name indicates the number of leaves in onc fascicle.) 
[I] Fibro-vascular bundle single . . . Subgenus I. Haploxylon KoEHNe

(A) Resin canals modial, i e. situated in the green tissue, touching neither hypoderm nor endoderm. Endoderm circular. Stomata on the ventral side only.

$\left(a_{0}\right)$ Resin canals 2 , in the green tissue nearer to the hypocierm of the dorsal side. Stomata on each ventral side 3,4 or $5 .$. . . .

$\left(b_{0}\right)$ Resin canals 3 , often 5,3 of them confined to each ecige. Stomata on each ventral side 4 to 13 . Hypoclerm consisting of one layer of thin-walled cells. . . . . P. koraiensis SIEB et ZuCC. (5).

(B) Resin canals medial and external, i.e. some of resin canals situated in the rreen tissue, touching neither endoderm nor hopoderm, but others close to the hypoderm. Indoderm circular.

$\left(a_{0}\right)$ Stomata on the ventral side only. Resin canals 3, dorsal 2 of them external and ventral one medial. . . P. Armandi Francir. (5).

(bo) Stomata on both dorsal and ventral sides. Resin canals 3 to 5. Hypoderm 2 or 3 layers of thick-walled cells, though occasionally consisting of one layer of cells. . . P. Lambertiana Dolglas (5).

(C) Rcsin canals external, i.e. situated close to the hypoderm.

$\left(a_{0}\right)$ Stomata on the ventral side only.

$\left(a_{1}\right)$ Endoderm circular.

$\left(a_{2}\right)$ External resin canals dorsal and ventral.

$\left(a_{3}\right)$ Total number of resin canals 3 .

$\left(a_{4}\right)$ Hypoderm mostly one layer of thin-walled cells.

$\left(a_{5}\right)$ Sclerenchyma cell deficient above and below the

fibro-vascular bundle. Stomata on each ventral side 2 , rarely 3 or 4 . .

P. strobus $\mathrm{L}$. (5).

$\left(b_{5}\right)$ Several sclerenchyma cells lie scattered below the fibrovascular bunclle, rarely below and above. Stomata 4 to 6 on each ventral sicle. .. . . . . . . . . . . . . . . . . . . . .

P. formosana Hayata (5), P. Uyematsui Hayata (5).

$\left(b_{4}\right)$ Hypoderm, some parts consisting of one layer of cells and others of 2 layers, especially 2-3 layers in the cogge.

$\left(a_{5}\right)$ Hypoderm cells thin-walled, not shiny white. Sclercnchyma cells surrounding the resin canals always continuous. Stomata $3 m_{4}$ on each ventral side. . P. monticula Douglas (5).

$\left(b_{5}\right)$ Hypoderm cells thick-walled, somewhat shiny white. The Sclcrenchyma cells surrounding the resin canals are wanting 
at the point touching the hypudem and the ecreting cells are close to the lypoderm. Stumati 3 to 5 on each ventral side.

(b) Total number of resin canals 4 wo 8 . . . . . P. ayacalunite Ehrenberg (5).

(b.) Fixternal resin canals in the dorsal side only, one or two.

(a) Resin canal onc of two, situated ncarer to the middle part of the dorsal sicie, namely undemeath the cndodcm.

(a) Jypoderm consinting of one layer of thin-walled cells, weak. r. punila REgEL (5).

(b.) Hypoderm, some partis consisting of one layer of thick-walled colls and others of two layers, especially 2-3 layers at the edge, shiny white. . . . . . . P. aristato ExGElm. (5).

(b) Two resin canals separated from each other, situated on the dorsal sicle of the bypoclerm.

$\left(a_{4}\right)$ The angle formed between the two ventral sides larger than a right angle, approximatcly $120^{\circ}$. Hypoderm cells thickwalled. Stomata 3 to 5 w each ventral side. .

P. cembroides ZUCCAR. (3). P. Pinceana GoRdon (3). ( $P$. Pinceana is easily distinguished from $l$. cembroides by the greater length of its leaf.)

$\left(b_{4}\right)$ The angle formed between the two ventral sides smaller than a right angle, approximately $72^{\circ}$.

$\left(a_{5}\right)$ llypoderm consisting of one layer of cells.

Stomata $4, ; 0 \%$ on cach ventral side.

$\left(a_{6}\right)$ Several sclerenchyma cells lie scattered below the fibro-rascular bundle, often below and above.

$\left(a_{3}\right)$ Hypoterm cells rery thin-walled, uniform. $P$. parriflori Sieb. et Zucc. (5), P. pentaphyllex MaYR (5).

$\left(b_{7}\right)$ Hypoderm cells with both thick and thin

walls. P. amamana Kolnz. (5), I' formosan HayaTa (5), $P$. (iyematsui Hayata (5).

(b) The sclerenchyma cells are wanting above and below the fibro-vascular bunde.

(a) Hypuderm one layer of cells, weak.

$\left(a_{8}\right)$ Stomata 2 , often 3 or 4 un each rentral side. I eaves of to It cm long. . . . . . . P. strobus L. (5).

$\left(b_{3}\right)$ Stomatia ito 6 on each ventral side Leaves 10 to $18 \mathrm{~cm}$ long. . . . . . P. excelsi Walrich (5). 
(b) Hypoderm for the most part consisting of one layer of cells, anct others of two layers. Leaves 7 to $10 \mathrm{~cm}$. long. P. peuce Gristin (5). $\left(b_{5}\right)$ Hypoderm, some parts consisting of one layer of cells and others of two or three layers, especially 2-3 laycrs at the edge.

(o.) The sclerenchyma cells surroundins the resin canals are wanting at 1 he point touching the hypoderm and the secreting cells are close to the hypodern. Hypodern for the most part consisting of 2 or 3 layers of thick-walled cells. Stomata 3 to 5 on each ventral side. P. quadrifolia SLDworter (4). canals are continuous.

$\left(\mathrm{b}_{6}\right)$ The sclerechyma cells surmonding the resin

(a) Hypoderm celis thin-walled, not shiny white. The cells surrounding the resin canals thin-walled. The sclerenchyma cells are wanting below and above the fibro-vascular bundle. Stomata 3 or 4 on eacli ventral side. . . . . $P$. monticola Douglas (5).

(b) Hypoderm cclls very thick-walled, shiny white. Several scicronchyma cells lie scattered below the fibro-vascular bundle. The cells surrounding the resin canals thick-walled. Stomata 4 to 6 on each ventral side. . . . . . P. Balfouriana Murray (5).

$\left(b_{1}\right)$ Fndocerm small, broad-elliptical.

Resin cancls 2. Hypoderm colls thick-walled. Stomata 3 to 5 on each ventral side. , $P$. cembroides Zccc. (3), P. Pinceana Condor (3). (P. Pincexna are exsily distinguished from $P$. cembroiles by the greater length of their leaves.)

(bo) Stomata on both dorsal and ventral sides.

(a) Encocerm circular.

$\left(\mathrm{a}_{2}\right)$ Transierse section of the leaf circular.

Many sclerenchma cells form irregular lines below and above the fibro-vascular buntle, silvery. Resin canals 4 to 9. Hypocerm I-3 layers of very thick-walled cells, silvery. P. monophylla Torrey (1).

$\left(b_{2}\right)$ Transwerse section of the leaf tringular.

$\left(a_{3}\right)$ Resin canals two, rarely one.

$\left(a_{4}\right)$ The angle formed between the two ventral sides larger than a right ang!e, approximately $120^{\circ}$.

(a) Stomata one on each ventral sice, often two

Resin canals one or two, very small, almost buried in the hyporlerm.

P. Nelsonii SHaw (3). 
(b) Stomata 3 to 5 on each ventral side. Resin canals 2. . . . I'. combroides Zcccir. (3), I'. Pinceana Gordon (3). ( $P$. Pinceanc are casily distinguished from $I$ '. cembroides by the greater length of their leaves.)

$\left(b_{4}\right)$ The angle formed between the two ventral sicles smaller than a right angle, approxinately $72^{\circ}$. Stomata 3,4 or 5 on each ventral side.

(a) The outer walls of the endoderm thick.

Hypodem une layer of thin-walled cells, inconspicuous. Stomata very obvious. Resin canal large. . . . . . I'. albicaulis ENGelm. (5).

$\left(b_{5}\right)$ The outer walls of the endodern cells not thick.

(a) Hypoderm, some parts consisting of one layer of cells and others of two layers.

(a) Iypokerm cells thin-walled. The cells surrounding the tesin canals thin-nalled. Stomata 3 or 4 on each ventral side, sometimes on dorsal sirle. The sclerenchyma cells are wanting below and above the fibro-vascular bundle. . . . . . . . . . . . . . . . ... . . 1' monticola Douglas (5) (rare case).

(b, Hypoderm cells thick-walled, shiny white. Stomata nsually on both dorsal and ventral sicies, on each ventral side 3. often 4. Several sclerenchyma cells lie scattered below and above the fibro-viscular bundle. . . . . . . . l. flexilis James (5).

(b6) Hypoderm for the most part consisting of 2 or 3 layers of thich-walled cells, others of one layer.

I. Lambertiand J)ougLas (5).

(b) Resin candis 3 to 7 .

$\left(a_{4}\right)$ Iypoticrm for the thesst part consisting of one layer of thin-walled cells, olhers of two layers. The cells surrounding the resin canals very thin-walled. The angle formed between the two ventral

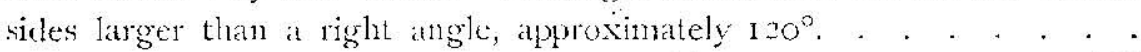
. . . . . '. Bungeana Zuccar. (3), I'. Gerardiana Wald. (3). ( $P$. Cierartiana is distinguished from $I$. Bunganu by its denser, Jonger, and more slender leaves.)

(1) Hypoleru for the nost part consisting of 2 or 3 layers of thick-walled colls, others of une layer. The angle formed between the two ventral sicles smaller than a right angle, approximately $72^{\circ}$. . . . . . . . . . P. Lambertiana Dotglas (5). 
(b) Endoderm small, broad-elliptical.

$\left(a_{2}\right)$ Resin canals in dorsal side two, sometimes one.

$\left(a_{3}\right)$ Stomata one, often two on each ventral side.

Resin canals one or two, very small, almost buried in the hypoderm.

P. Nelsonii Shaw (3)

$\left(b_{3}\right)$ Stomata 3 to 5 on each ventral side.

Resin canals usually two Hypodern one or two layers of cells.

$\left(a_{4}\right)$ Transverse section of a leaf semicircular.

P. edulis Fxaklm. (2).

$\left(b_{4}\right)$ Transverse section of a leaf triangular.

Hypoderm cells thick-walled.

. . . . . . P. cembroides Zuccar. (3), P. Pinceana Gondor (3).

(P. Pinceana are easily distinguished from $l$ '. cembroides by the greater length of their leaves.)

often 9 .

(b.) Resin canals in the dorsal and ventral sides, 3 to 7 ,

$\left(a_{3}\right)$ The many sclerenchyma cells forming irregular lines below and above the fibro-vascular bundle, silvery. Transverse section of a leaf circular. Resin canals 4 to 9. Hypoderm $\mathrm{I}-3$ layers of very thick-walled cells, silvery. . . . . . . P. monophylla Torkey (1)

$\left(b_{3}\right)$ The sclerenchyma sells deficient below and above the fibro-vascular bundle. Transverse section of a leaf triangular. Resin canals 3 to 6 . Stomata 4 or 5 , rarely 6 on each ventral side. Hypoclerm for the most part consisting of one layer of cells, others of 2 or 3 layers. . . . . . . P. Bungeana Zucc. (3), I. Gerartiana WaLL (3). (1). Gerardiana is distinguished from $P$. Bungarna by its clenser, longer. ani more siender leaves.)

[11] Jiblur-vascular bundles double. . . . Sulgrenus II. Diploxoylon KoEHNe.

(A) Resin canais internal, i.e. situated close to the endodern.

Stomata on both dorsal and ventral sicles Ilypocerm biform, namely very thin walls situated in the outer layer of cells and rery thick walls in the inner layer or layers of cells. Resin canals 2 to 5 .

(a) Iypoderm in thick masses, projecting far in to the green tissue and sometimes touching the endolerm. The sclerenchyma cells forming irregular lines below and above the fibro-atscular bundles.

Resin canals 2 or 3. . . . . . . . . . P. Pringlei Shaw (3). 
$\left(b_{o}\right)$ Hypoderm not projecting far in to the green tissue, not touching the endoderm. Endoderm with thin suter walls.

$\left(a_{1}\right)$ The sclerenchyma cells developing distinctly, forming irregular lines below and above the fibro-vascular bundles, sometimes lying between the two bundles forming "II" shape. Resin canals 3 or 4 Endoderm triangular or elliptical Hypoderm 3 or 4 layers of cells.

(b) The sclerenchyma cells form an irregular line below the fibro-vascular bundles, but are wanting above the bundles Findorlerm long-based triangular or elliptical. Resin canals 2 to 5

$\left(a_{2}\right)$ Hypoderm, some parts consisting of one layer of cells and others of two layers, biform when of 2 layers.

(b) Hypoderm consisting of 3 layers of cells occasionally of 2 or 4 layers of cells. Several sclerenchyma cells lie scattered below the fibro-vascular bundles. (Terives not excecing $24 \mathrm{~cm}$. in length) . P. Lazesonii Rocz. (3, 4 or 5 ).

(c.) Hypodern 3 to 6 layers of cells. The sclerenchyna cells continuous and forning an irregular line below the fibro-vascular bundles (Leaves $24-45 \mathrm{~cm}$. in length). . . P. palustris Mruter (3).

(B) Resin cands internal and medial, i.e. some of the resin canals situated close to the endoderm, but others in the green tissue, touching neither endoderm nor hypoderm. Stomata on both dorsal and ventral sides.

(a) Endoderm triangular. Transverse section of a leaf triangular. (a) Hypoderm uniform, weak.

(a) Resin canals 3 .

$\left(a_{3}\right)$ Endoderm regular-triangular. The angle formed between the two ventral sides smaller than a right angle, approximately $72^{\circ}$. . . . . . . . . P. leiophylla Schlechis et Cham. (5).

$\left(b_{3}\right)$ Endoderm long-based triangular. The angle formed between the two ventral sides larger than a right angle, approximately I $20^{\circ}$. Hypoderm consisting of one layer of thin-walled cells, occasionally of two layers of cells. . . P. patula Scnilecht. et Chalr. (3, or 4,5 ).

$\left(b_{2}\right)$ Resin canals 4 to ro

Hypoderm one or two layers of cells.

P. Latmholtzii RoBins, et FERN. (3).

$\left(b_{1}\right)$ Hypoderm biform, $i$ e. very thin walls situated in the 
outer layer of cells and very thick walls in the inner layer or layers of cells.

$\left(a_{2}\right)$ The outer walls of the endoderm cells thick. Hypoderm consisting of 2 or 3 layers of cells. Two of three resin canals medial and with one internal canal.

I. Leocote Scinecilt. ef Cimam. (3-5)

$\left(b_{2}\right)$ The onter walls of the endorerm-celli not thick.

(a) Hypoderm, some parts consisting of one layer of cells and others of two layers, biform when of two layers. Fndoderm with thin outer walls.

$\left(a_{4}\right)$ Two resin cands in the lateral cdges always medial, and very large. Outer cells of the hypodem very small and inconspicuous. Total number of resin canals 3 to

P. echimatr Milier ( 2 or 3 , case of 3 ).

$\left(b_{4}\right)$ Two resin canals in the lateral edges internal, occasionally internal and medial or medial, nearer to the endoderm, and small. Outer cells of the hypoderm not small Total number of resin canals 3 to 5. . . P. caribara Morelet ( 2 o 3. case of 3)

$\left(b_{3}\right)$ Hypoderm for the most part consisting of 2 layers of cells, occasionally of 3 layers of cells. Resin canals 2 to 6

- P attenuata Lemmon (3), P. serotina Michuux (3). P. taeda I. (3)

$\left(c_{3}\right)$ Hyporlerm for the most part consisting of 3 layers of cells, occasionally of 2 or 4 layers of cells. Findoderm with thin outer walls. Resin canals 3 or 4. . . P. Lazusonii RoEzL (3, often 5).

$\left(d_{3}\right)$ Hypoderm 2 to 6 layers of cells.

Resin canals 2 to 8. . . . . . . . P. rigida Millek (3).

(c) Hypodem multiform, i.e. cell walls being gradnally thicker toward the centre of the leaf. Endoderm-cells with both thick and thin outer walls. Resin canals 2 to 10. . P. Coulteri D. Don (3).

$\left(b_{0}\right)$ Findoderm elliptical. Transverse section of a leaf semicircular.

(Reference 174 p. $\left(B-a_{0}\right)$ on the species which the transverse section of a leaf are triangular.)

(ar) Hypoderm uniform.

Two resin canals medial and with an internal canal. Hypoderm 2-3 layers of thick walled cells. Endoderm-cells very unequal in size, some of them large. . . . P. Merkusii Jungh ot De Vriese (2).

$\left(b_{x}\right)$ Hypoderm biform, i.c. very thin walls situated in the 
outer layer of cells and very thick walls in the inner layer or layers of cells.

$\left(a_{2}\right)$ Hypodern, some parts consisting of one layer of cells and others of two layers, biform when of two layers of cells. Endoderm with thin outer walls.

$\left(a_{3}\right)$ Two resin canals in the lateral edges internal, occasionally internal and medial or medial, nearer to the endoderm. Resin canals 3 to 5. (Leaves 12 to $25 \mathrm{~cm}$. long.). . . . . . $P$. caribaea MoRelet ( 2 or 3 , case of 2 ).

$\left(b_{3}\right)$ Two resin canals in the lateral edges always medial. (a) Medial resin canals 3 or more, 2 of them in the lateral edges and very large. Outer cells of the hypoderm very small and inconspicuous. Total number of resin canals 4 to 7 . (I eaves 7 to $12 \mathrm{~cm}$. long). . . . . P. cchinata Miller 2 or 3 , case of 2 )

$\left(\mathrm{b}_{4}\right)$ Medial resin canals 2 , confined to lateral edges. Total number of resin canals 3 . Outer cells of the hypoclerm not small. (Leaves 5 to 9 cm. long.) . . . . . . . . P. clausa VAsEx (2). $\left(b_{2}\right)$ Hypodern consisting of 2 layers of cells, occasionally of 3 layers of cells.

(a) Medial resin canals 2 or 3 , occasionally with an internal canal.

(a) Resin canals 3 . I eaves 4 to $8 \mathrm{~cm}$. long. . .

(b) Resin canals 4 Leaves io to $15 \mathrm{~cm}$ long P. radiata D. Don ( 2 or 3 ).

$\left(b_{3}\right)$ Medial resin canals 4 to 6 , occasionally with an internal canal. I.eaves 3 to $7 \mathrm{~cm}$. long. . P. pungens Lambert (2).

(C) Resin canals internal and septal, i.e. some of the resin canals situated close to the endoderm, and others touching both the endoderm and hypoderm, forming a septum. Stomata on both dorsal and ventral sides.

$\left(a_{\circ}\right)$ Endoderm regular-triangular or short-based triangular.

Resin canals one to six, mostly septal. Hypoderm biform or multiform, projecting far in to the grcen tissue, but not touching the endoderm. The sclerenchyma cells forming irregular lines below and above the fibro-vascular bundles. . . P oocarpe Schrede (3, 4 or 5 ) (rare case)

$\left(b_{0}\right)$ Endoderm long-based triangular or elliptical

Resin canals 3, mostly internal. Hypoderm biform, in thick masses, projecting far in to the green tissue and sometimes touching the endo- 
derm. The sclerenchyma cells forming irrcgular lines below and above the fibro-vascular bundles . . . . . . . . P. Pringlei Sraw (3).

(D) Resin canals septal, i.e. situated close to both the encloderm and hypoderm, forming a septum. Stomata on both dorsal and ventral sides.

$\left(a_{o}\right)$ Endoderm triangular. Hypoderm biform or multiform, projecting far in to the green tissue, but not touching the endoderm. Resin canals one to six. The sclerenchyma cells forming irregular lines below and above the fibro-vascular bundles.

I. oocarpe Scilledi: $(3,4$ or 5$)$.

$\left(b_{o}\right)$ lindoderm elliptical. Hypoderm cells uniform thick-walled. Resin canals of remarkable size, 2 to 9 . The sclerenchyma cells not only form irregular lines below and above the fibro-vascular bundles, but also lie scattered between the 2 bundles forming " $1:$ " shape. . . L'. tropicalis Mokelex (2).

(I) Resin canals spptal and medial, i e. some of the resin canals situated close to both the endokerm and hypoderm, forming a septum, but others in the green tissue, touching neither the endoclem nor hypodem. Stomata on both dorsal and ventral sides. Endociem elliptical. Medial resin canals 2 and with at septal canal. Endodermcells very unequal in size, some of them large. Hypoderm cells uniform thick-walled. . . . P. Merkusii Jungn. et I)E Vriest: (2).

(F) Resin canals septal and technically external, $i$ e. some of the resin canals situated close to both the endoderm and hypoderm, forming a septum, but others touching a remarkably developed hypoderm. Stomata on both dorsal and ventral sides.

(a) Resin canals 2 to 4 , small. Hypoderm in large masses, projecting far in to the green tissue. Fndoderm long-based triangular, with thin outer walls. . . . . . . . . l? canctriensis Snirn (3).

(b) Resin canals of remarkable size, 2 to 9 . Hypoderm not projecting far in to the green tissue, with uniform thick-walled cells. Endoderm elliptical. The sclerenchyma cells not only form irregular lines below and above fibro-vascular bundies, but also lie cattered between the 2 bundles forming " $\mathrm{T}$." shape.

1. tropicalis MORELET (2).

(G) Resin canals medial, i.e. situated in the green tissue, touching neither the endoderm nor hypoderm. Stomata on both dorsal and ventral sides.

$\left(a_{0}\right)$ Endoderm triangular. 


\section{(a) Hypoderm uniform.}

(a) The onter walls of the entoderm thick.

(a) Ilypoiem 2 to 4 layers of thick-walled cells, not extending te the endorlem:

(a) The sclerenchyma cells form irregular lines below and athore the fibro-vascular bundles.

Endixdem regulat-trangular. Resin canals 3 or 4 , 3 of them confuned to 3 edges. The angle formed between the two ventral sides smaller than a right angle, appruximately $72^{\circ}$. . P pseztostrobus L.INDL. (5).

$\left(b_{4}\right)$ Lhe sclerenchyma cells form an irregular line below the fibro-vascular bundles.

$\left\{\left(a_{5}\right)\right.$ Leaves $30-40 \mathrm{~cm}$. in lengl . . . . . . . . . Engelnamia Carrive (3-5).

(b5) Leaves $7-25 \mathrm{~cm}$. in length.

$\left(a_{t}\right)$ findoderm long-based triangular. The angle formed between the two rentral sides larger than it right angle, approximately $120^{\circ}$. Leaves $12-25 \mathrm{~cm}$. long.

$\left(a_{7}\right)$ The sclerenchyma cells form an irregular line below the fibro-vascular bundles, but are wanting above the bundles. Leaves deep yellowish green. . P. ponderosa Douglas (3).

(b) The many sclerenchyma cells form an irregular line below the fibro-vascular bundles and several of them are scattered above the bundles. Leaves grayish green.

P. Jeffreyi batanour (3-5)

(b) Fndoderm regular-triangular. The angle cormed between the two ventral sides smaller than at right angle, approximatcly $7^{2}$.

(a) Leaves deep green, fine scrrated, $7-17 \mathrm{~cm}$. lung. . . . . . . . . . . P arizonica ENGELM. (5).

(b) Leaves; grayjsh green, $12-25 \mathrm{~cm}$. long. . I. Jeffreyi Balfour (3-5).

(b) Hypokerm remarkably develuped, extending from the epickm th the endukem and forming a septun across the green tissite: Resin an ils 2 is 3 , contined to the edges. The sclerenclyomat cells forming inegular lines below and above the fibro-sascular bundles P. pseutostrobus inar. temuifolia SHaw (5)

(b.) The outer walls of the endoderm not thick.

(a) Resin canals 2. 
$\left(a_{4}\right)$ Fibro-vascular bundles distinct. The angle formed between the two ventral sides larger than a right angle, approximately $120^{\circ}$.

$\left(a_{5}\right)$ Hypodem one layer of thin-walled cells, inconspicuous. Medial resin canals two, occasionally with an internal canal. . . . . . . . . . . . P. patula Scilleche et Cham. (3).

$\left(b_{5}\right)$ Hypoderm 2 to 3 layers of thin-walled cells. Resin canals always medial. . . . . . . P. Greggii ENGelm. (3).

$\left(\mathrm{b}_{4}\right)$ Fibro-vascular bundles ccntiguous or merged in one. The angle formed between the two ventral sides smaller than a right angle, approximately $72^{\circ}$. Hypoderm one or two layers of cells. . . . . . . . . 2. leiophylla Schlecht. et Chas. (5).

$\left(b_{3}\right)$ Resin canals 3 to 6 . Hypoderm 2 or 3 layers of cells. Fibro-vascular bundiles distinct or contiguous. The angle formed between the'two ventral sides larger than a right angle, approximately $12 \mathrm{O}^{\circ}$. . . . . . . . . . . . P. chihuahuana Engelm. (3).

$\left(c_{2}\right)$ The leaf-scction is notable for the presence of both thick and thin outer walls of the endoderm-cells and for the large amount of the hypolerm, both forms appearing in the same leaf. Three resin canals confined to the 3 edges. . . . P. Torreyana PARry (5).

(b) Hypoderm Liform, i.e. very thin walls situated in the outer layer of cells and very thick walls in the inner layer or layers of cells. Transverse section of a leaf triangular.

$\left(a_{2}\right)$ The outer walls of the endederm-cells thick.

Hypoderm 2 or 3 layers of cells. Resin canals 2 or 3 , confined to the edges. . . . . . . . P. teocote Schlecir'. et Cham. (3-5).

$\left(b_{2}\right)$ The outer walls of the endoderm-cells not thick.

$\left(a_{3}\right)$ Hypodern in some parts consisting of one layer of cells, and in others of two layers, bifom when of two layers of cells. Resin canals 2 to 6,2 of them nearer to the eilges, very large. Outer cells of the hypoderm very small, inconspicuons. Endoderm with thin outer walls. . . . . . 1. echinata MiLLex ( 2 or 3 . citic of 3 ).

(b) Hypolerm consisting of 2 layers of cells, occasionally of 3 layers of cells.

(a) The cell walls of the stelar tissue thick. Kesin canals 2 or 3 . . . . P. radiata D. Dox (2 or 3 , case of 3 ).

$\left(b_{4}\right)$ The cell walls of the stelar tissue thin. Resin

canals 2 to 6.

$P$. attenuata Lemmon (3), P. serotina Michacx (3), P. taeda L. (3). 
$\left(c_{3}\right)$ Hypoderm 2 to 6 laycrs of cells.

Resin canals 2 to $8 .$. . . . . . . . . P. rigida Muller (3).

$\left(c_{1}\right)$ Hypederm multiform, ice cell walls being gradually thicker toward the centre of the leaf.

$\left(a_{2}\right)$ The outer walls of the endroterm thick. Hypoderm 4 or 5 layers of cells.

(a) Irypodem projecting far in to the green lisste, but not extending to the endoderm. Resin canals 2 to 9 .

$\left(a_{4}\right)$ The solerenclyma cells form irregular lines below and abose the fibro-vascular bundles.

$\left\{\left(a_{5}\right)\right.$ Number of the resin canals usually $3 . .$.

(b) Number of the resil canals 1 or 2 , often 3 .

Leaves $15-25 \mathrm{~cm}$ in length, often very slender and drooping. . .

- . . P Montezmat are Lindley Lounox (3-8).

$\left(c_{5}\right)$ Number of the resin canals 4,5 or more.

Ieaves short $(7-15 \mathrm{~cm}$ long), rigid, glaucoms.

$\left(a_{6}\right)$ Resin canals 4 or 5 . I eaves are in fascicles of 5 , occasionally more, IO- $15 \mathrm{~cm}$. in lengtls.

. . . . . . . . P montezunat rat rudis SHaw $(5-8)$.

$\left(\mathrm{b}_{6}\right)$ Resin canals numerous, 7 -ro. Ieaves arc in fascicles of 3 and 4 as well as $5,7-15 \mathrm{~cm}$. in length.

P. Montezunae var. Hartaegii ExGen. (3-5).

$\left(b_{4}\right)$ The sclerenchyna cells forming an irregular line bclow the fibro-vascular bundles.

$\left\{\left(a_{5}\right)\right.$ Leaves $30-40 \mathrm{~cm}$. in length.

P. Engelmannii CARRIÈre (3-5).

$\left(b_{5}\right)$ Leaves $7-25 \mathrm{~cm}$. in letigth.

$\left(a_{6}\right)$ Endoderm long-based triangular. The angle

formed between the two ventral sides larger than a right angle, approximately $120^{\circ}$. Leaves $12-25 \mathrm{~cm}$. long.

(a) The sclerenchyma cells form an irregular line below the fibro-vascular bundles, but are wanting above the bundles. I.eaves deep yelowish green. . . . . . P. ponderosa Docgras (3).

$\left(b_{7}\right)$ The many sclerenclyma cells form an irregular line below the fibro-vascular bundles and several of them are scattered above the bundles. L.eaves grayish green 
$\left(\mathrm{b}_{6}\right)$ Endoderm regular-triangular. The angle formed between the two ventral sides smaller than a right angle, approximately $72^{\circ}$.

$\left(a_{7}\right)$ Leaves deep green, fine serrated, 7-1 7 $\mathrm{cm}$ long. . . . . . . . . . . . . . P. arizonica Exgelm. (j).

$\left(b_{7}\right)$ I eaves grayish green, $12-25 \mathrm{~cm}$. long. . P. Feffreyi BALFOUR (3-5).

$\left(\mathrm{b}_{3}\right)$ Jypoderm remarliably developed, extending from the epiderm to the endoderm and forming a septum across the green tissue. Resin canals 2 or 3 , confined to the colges. The sclerenchyma celis forming irregular lines below and above the fibro-vascular bundies . . . . . . . . . P. psezdostrobus var. tenuifolia SHaw (5).

$\left(b_{2}\right)$ The leaf-section is notable for the presence of both thick and thin outer walls of the enduderm-cells and for the large amount of the hypoderm, both forms appearing in the same leaf.

$\left(a_{3}\right)$ lindoderm regular-triangular. Resin canals 3, confined to the 3 edges. Hypoxierm 5 to 7 layers of cells. The many sclerenchyma cells forming irregular lines below and above the fibrovascular bundles. The angic formed between the two ventral sides smaller than a right angle, approximately $72^{\circ}$.

$\left(b_{3}\right)$ Lindodern long-based triangular. Resin canals 2 to 10, taking frec portion. The angle formed between the two ventral sides larger than a right angle, approximately $120^{\circ}$.

(a) Hypoderm 2-4 layers of cells. Numerous resin canals always nedial. The sclerenchyma cclls not only form irregular lines below and above the fibro-vascular bundles, but also lie between the two bundles forming " $x$ " shape. . . P. Sabiniana Dotglas (3).

$\left(\mathrm{b}_{4}\right)$ Hypoderm consisting of $5-7$ layers of cells.

Resin canals medial, or occasionally with one or two internal canals. . . . . . . . . . . . . . . . P. Coulteri D. Dor (3). (bo) Endoderm elliptical.

$\left(a_{1}\right)$ Ilypoderm cells uniform thick-wallect.

$\left(a_{2}\right)$ The outer walls of the endoderm thich. Resin canais 2 to 9 . Hypoderm 2 or 3 layers of cells. $\left\{\left(a_{3}\right)\right.$ Leaves $30-40 \mathrm{~cm}$. in length.

$\left(b_{3}\right)$ Leaves $12-25 \mathrm{~cm}$. in length. 
(a) The sclerenchyma cells form an irregular line below the fibro-vascular bundles, but wanting above the bundles. Leaves deep yellowish green. . . . . . 1. ponderosa Docglas (3).

$\left(b_{4}\right)$ The many sclerenchyma cells form an irregular line below the fibro-vascular bundles and several of them are scattered above the bundles. Leaves grayish green.

$\left(b_{2}\right)$ The outer walls of the endoderm not thick.

P. feffreyi Barfouk $(3-5)$

$\left(a_{3}\right)$ Endoderm-cells very unequal in size, some of them large. Two resin canals medial, but occasionally with an internal canal or a septal canal. Hypoderm 2 or 3 layers of cells.

. . . . . . . . . 1 1? Merkusii Jungh. et De VRIese (2).

$\left(b_{3}\right)$ Endoderm-cells approximately equal in size.

$\left(a_{4}\right)$ Transverse section of a leaf triangular.

Fibro-vascular bundles contiguous. Resin canals 3 to 6 .

P. chiluatuana ExGEM. (3).

$\left(\mathrm{b}_{4}\right)$ Transverse section of a leaf semicircular.

$\left(a_{5}\right)$ The sclerenchyma cells not only form irregular lines below and above the fibro-vascular bundles, but also lic scattered between the 2 bundles forming " $f$." shape. Hypoderm 2 to 3 layers of thick-walled cells. Resin canals 2 to I I, always medial . . . . . . . . . . . . . . . . . P. leucodermis Aniolne (2).

$\left(b_{5}\right)$ The sclerenchyma cells form irregular lines below and above the fibro-vascular bundles, but not forming "I" shape. IIypoderm consisting of one layer of celis, occasionally of two layers of cells. Resin canals 2 to 6 , medial or medial and external.

- . . . P. tizizanensis Hayata (2), P. bremispica Hayata (2).

$\left(c_{5}\right)$ The sclerenchyma cells form a irregular line below the fibro-vascular bundles, occasionally several of them lie scattered above the bundles.

(a $a_{6}$ Hypoderm, some parts consisting of one layer of cells and others of two layers. Resin canals 2 or 3 . Lipidern very thick. The sclerenchyma cells lie scattered and form a irregular line below the fibro-vascular bundles, but are wanting above the bundles I. luchensis MAYR (2).

(b) Hypoderm consisting of 2 layers of very thick-walled cells, occasionally of 3 layers of cells. Resin canals 2 to I2, often to 5 . The sclerenchyma cells forming an irregular line below 
the fibro-vascular bundles, and several of them lie scattered above the

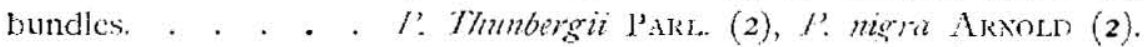

(b) Hypoderm cells uniform thin-walled.

(a.) Hypoderm consisting of one layer of thin-walled incunspicusus cells, occasionally of 2 layers of cells.

$\left(a_{3}\right)$ The sclerenclyma cells forming irregular lines below and above the fibro-vascular bundles. Resin canals 2 to 6 , merlial or medial and external. Transverse section of a leaf semicircular. . .

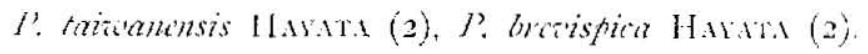

(b) Screral sclesenchyma cells lie scattered below the fibro-bascular bundles. Medial resin canals two, occasionally with an internal canal. Transverse section of a leaf triangular.

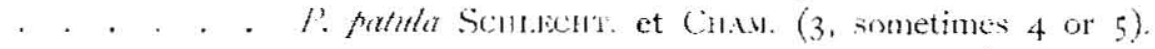

(b.) I Iypoderm consisting of 2 to 3 layers of cells.

Resin canals 2, always medial' . . . . . I'. Greggri Exglelas. (3).

(c) Hypolerm biform, i.e. very thin walls situated in the outer layer of cells and very thick walls in the immer layer or layers of cells. 'lransverse section of a leaf semicircular.

(Reference p. $179 \quad\left(b_{t}\right)$ an the species which the transverse section of a leaf are triangular.)

$\left(a_{2}\right)$ Iypolerm, some parts consisting of one layer of cell: and others of two layers, hiform when of two layers of calls.

(a.) Outer cells of the lyypodern very small, inconspicuous. Einduderm wilh thin outer walls.

$\left(a_{4}\right)$ Resin canals 2 to 6 , medial or medial and internal : 2 medial canals of them nearer to the edges, very large.

. . . . . . . . P' colinata Mittek (2 or 3, case of 2).

(b) Resin canals always 2, medial, confined to the edges, not large. . . . . . . . . . I. glabre WaLtek (2).

(b) Outer cells of the hypoderm large, conspicnous. Medial remin canals two, or occasionally with an intenal canal. . . l. clatust VAsti: (2)

(b) liypodem consisting of 2 or 3 layers of cells.

(a) Resin canals 2.

$\left(a_{4}\right)$ Ifypoderm usually 2 layers of cells. Leaves 4 to $8 \mathrm{~cm}$ long. . . . . . . . . . . . P. arginiama Mili.er (2). $\left(b_{*}\right)$ Hypolerm 2 layers of cells, but having parts 
which consist of 3 layers of cells. Leaves 10 to $15 \mathrm{~cm}$. long. $P$. radiata D. Don ( 2 or 3 , case of 2 ). $\left\{\left(b_{3}\right)\right.$ Resin canals 3 to 6.

(a $a_{4}$ I eaves from 3 to $7 \mathrm{~cm}$. long. Resin canals 3 to 6 , medial or medial and intcrual. . . . . P. pungens LamberT (2).

$\left(b_{4}\right)$ Leaves from 10 to $15 \mathrm{~cm}$. long.

$\left(a_{5}\right)$ Resin canals 2 or 3 , medial or medial and internal. . . . . . . P. radiata D. Don (2 or 3, case of 2).

(b) Resin canals 3 or 4 , always medial.

$\left(d_{s}\right)$ Hypuclerm multiforn, i.e. cell walls being gradually thicker toward the centre of the leaf.

$\left(a_{2}\right)$ The outer walls of the endoderm thick. Transverse section of a leaf triangular. Resin canals 2 to 9 .

$\left\{\left(a_{3}\right)\right.$ Leaves $30-40 \mathrm{~cm}$. in length

$\left(b_{3}\right)$ Leaves $12-25 \mathrm{~cm}$. in length.

$\left(a_{4}\right)$ The sclerenchyma cells form an irreguiar line below the fibro-vascular bundles, but are wanting above the bundles. Leaves deep yellowish grcen. . . . . . P. ponderosa Douglas (3).

$\left(b_{4}\right)$ The many sclerenchyma cells form an irregular line below the fibro-vascular bundles and several of then are scattered above the bundles. Leaves grayish green.

$$
\text { F. Jeffieyi BaLfol: }(3-5) \text {; }
$$

$\left(b_{2}\right)$ The unter walls of the endoderm not thick. Transverse section of a leaf semicircular. The inner cells of the hypoderm gradually larger, remarkably large in the edges. Resin canals 2 to 14 . . .

$$
\text { P. pinaster SOLANDER (2). }
$$

$\left(c_{2}\right)$ The leaf-section is notable for the presence of both thick and thin outer walls of the endoderm-cells and for the large amount of the hypoderm, both forms appearing in the same leaf. Resin canals 2 to 10 .

$\left(a_{3}\right)$ Iypoderm consisting of $2-4$ layers of cells. Numerous resin canals always medial. The sclerenchyma cells not only form irregular lines below and above the fibro-vascular bunlles, but also lic between the two bundles forming " $T$." shape 
(b) Hypoderm consisting of $5-7$ layers of cells. Resin canals medial, or occasionally with one or two internal canals. . . I. Conlteri I). I) (3)

(co) Fndodern siranglect-cisenus like.

The space between the two fibruasculas bundles wy wirke Resin canals wese of two. Hypolerm with refy thin walis in the onter layer of cells and very thich walls in the inner layer or layers of rells, namely biform. The outer walls of the endoderm thick.

$\left\{\left(a_{1}\right)\right.$ Ejpiderm cells thick, their thicknems thicker than theit

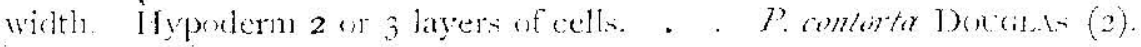

(b) Fipiem celle not thick, their thickness as long ats their

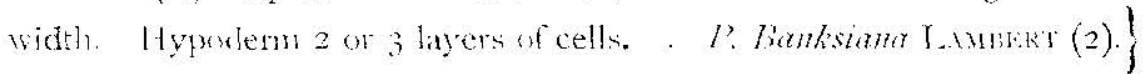

(H) Resin canals medial and extemal, i.c. sone of the resin canals situated in the green tisste, touching neither endedem nor hypodem; but others close to the hypodem. Stomata on both elorsal and ventral sides.

(a.) Endoderm long-batsed triangulas. Resin canals external, rarely with a medial canal in ventral side, 2 to 5 .

. . . . . . . . . . P. insularis ENuL. (3), (rare case).

(bo) Endoderm elliptical.

$\left(a_{1}\right)$ Resin canals 2 to 6 ; extemal canals usually 2 in the ventral side, medial canals in the clorsal side. Ilypoxterm comnisting of une layer of cells. The sclerenchyma cells surounding the resin camals thick. . . . . . . . . . . . . P resines AlTow (2).

$\left(b_{1}\right)$ Extemal resin canals in the chrsal sicle only or both the doral and ventral sides. Number of resin canals from 1 to 4 , often ti) II.

(a.) Transerse section of a leaf triangular. Resin canals 2 to 5. cxtemal or external and medial.

1. insulerzis Exur. (3), (ware case).

(b.). Transwerse section of a teaf semicirculat.

(a) The sclerenchyma cells forming inregular lines beles and alsue the fibrovitscular bundles. Resin canals 2 to 6 medial or medial and extemat. Ifypoderm consisting of one layer of cells, warely wi ayers wiselk.

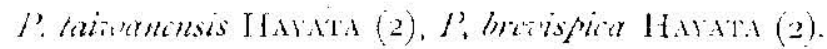

(bs) The sclerenchyma ceils cattercel and fomming a irregular line below the fibro-vascular bundles, occasionally several of 
them scattered above the bundles. Hyopoderm, some parts consisting of one layer of cells and others of two layers.

(a) Resin canals $3 ; 2$ of them medial, confined to the edges; other external in the dorsal side. Epiderm very thick. Hypoderm for the most part consisting of 2 layers of cells, others of one layer. . . . . . . . . . . . . P. luchuensis Mayr (2).

$\left(b_{+}\right)$Resin canals 2 to 12 , among them the medial canals taking free portion. Epiderm not so thick as $P$. lucluensis. Hypoderm for the must part consisting of one layer of cells, others of two layers. . . . . . . . . . . . . . . . . . . . . . - . P. densiflora X P. Thunbergii ; P. Thunbergii X P. densiftora MAvR

(c) Endoderm strangled-cocoon like.

The space between the lwo fibro-vascular bundles very wide. The sclerenchyma cells furming a irregular line below the fibro-vascular bundles, occasionally screral of then scattered above the bundles. The sclerenchyma ceils surrounding the resin canals continuous at the part touching the hypoderm. Resin canals 2 to 15 , external, wcasionally with one or two medial camals. Hypoderm one layer of thin-walled cells, often having parts which consist of two layers of cells. . . . .

(I) Resin canals external, i.e. situated close to the hypoderm.

Stomata on both dorsal and ventral sides.

(a. Endoderm triangular.

tissue.

(a) Hypoderm in Jarge masses, projecting far into the green

$\left(a_{2}\right)$ Some or all of the endoderm-cells with thick outer walls. Resin canals 2. . . . . . . . . I. longifolio Roxb. (3).

(b) Findoderm with thin outer walls. Resin canals 2 to 4 $P$. canariensis SMrTH (3).

$\left(b_{1}\right)$ Hypoderm nut projecting far in to the green tissue. Resin eanals 2 to 5, external, rarely with a medial canal. . . . . .

(bo) Enfodem elliptical.

$\left(a_{\mathrm{r}}\right)$ Hypoderm consisting of one layer of cells, occasional having parts consisting of two layers of cells.

$\left(a_{2}\right)$ External resin canals 2, in the ventral side only.

$\left(b_{2}\right)$ External resin canals in the dorsal side or both the dorsal and ventral sides. 
$\left(a_{3}\right)$ Epiderm remarkably thicl:

The sclerenchyma cells forming an irregular line below the fibrovascular bundles, occasionally several of them scattered above the bundles. Resin canals 2 to 7 . . . . . P. montana MLLer (2).

$\left(b_{3}\right)$ Epiderm not remarkably thick.

$\left(a_{4}\right)$ Transverse scction of a leaf triangular. Resin canals 2 to 5 . . . . . . . . . . . t. insularis Fxde. (3).

$\left(b_{4}\right)$ Transverse section of a leaf semicircular.

$\left(a_{5}\right)$ The sclerenclyma cells surrounding the resin canals are wanting at the part touching the hypoderm and several secreting cells are close to the hypoderm.

(a) The sclerenchyma cells forming an irregular line below the fibro-vascular bundles; nccasmatly scveral of then are scattered above the bundles.

(a) Iypodom consisting of ane layer of very thin-walled cells. Resin cants 2 to 12 . Jeaves 7 -1 2 cin. long. . . . . . . . . . . . . . . P. dizsiflori Si E⿺ et Zucc. (2).

(b) Hypodern consisting of one layer of thickwalled cells, but having parts which consist of two lavers of cells. Resin canals 2 to Io.

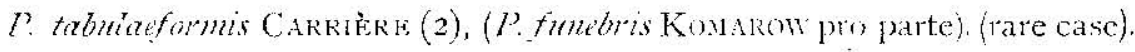

$\left(b_{6}\right)$ The several sclerenchyma cells scattered befow the fibro-vascular bundles, but not forning an irregular line, deficient above the bundles. Hypodern with very thin-walled cells, inconspicuous. Resin canals 5 to 8 . Leaves $\mathbf{2} 2-20 \mathrm{cmi}$ long

P. Massoniani I AMDERT (2, rarely 3).

$\left(b_{5}\right)$ The sclerenchyna cells surrounding the resin canals always continuous at the part touching the liypoderm. Resin canals 2, confined to lateral edges, one of $11 \mathrm{~cm}$ in the dorsal side and the other in the ventral side. Several sclerenchyma cells lic scattered below the fibro-vascular bundles. . . . . . . . P. pinea L. (2)

$\left(c_{5}\right)$ The sclerenchyma cells sumounding the resin canals continuous and surround the total circumference of some of the resin canals, but in other canals they are wanting at the parts touching the hypoderm, and secreting cells are close to the hypoderm. The sclerenchyma cells form an irregular line below the fibro-vascular bundles. occasionally several of them lie scattercd above the bundles. Hypoderm one layer of thick-walled cells, but having parts which 
consist of two layers of cells. Resin canals 2 to 10 .

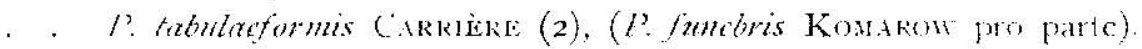

(b) Hypoderm consisting of 2 to 3 , rarely to 5 layers of uniform thick-walled cells.

(a) Resin canals of remarkal, se size, not douchings the endocem, techmically external, 2 to 9 . The solerenchyna colls form ing irregular lines below and abowe the fibrevascular bundles. Hypoderm 3 to 5 layers of cells. . . . . I. Hopicalis Molistel (2).

(b.) Kesin canals mot so large as 1'. trofiatis. The sclerenclyma celis forming an irregular line below the fibromasculat mondles, occasionally screral of them are scattered above the bundles.

(a) Resin canals 2 , contined to latoral cogges, one of then in the dorsal side and the other in the ventral side. The ecleren. chyma cells surrounding the resin canals always continuon at the part touching the hypulem. Several sclerenchyma cells lic scaticrest below the fibro-raxcular bundles. . . . . . . . . I'. pinte I. (2).

(b) Resin canalis 3 to 7 . takings free portion.

The scicrenchyma cells surrounding the rosin canals are continumb and surromel the total circunference of some of the resin canals, but in other canals they are wanting at the partis terching the hypotem and secreting cells are close to the hypolem . . . . . . . . . . . . . . . . . . . . . . . P. halepensis Mhlike (2). tisillc.

(c) Hypolem in large masses, projecting far into the green

(a.) Some or all of the cudodern-cels with thick wuter Walls. Kesin canali 2. . . . . . . . . 1. Kongifolia Roxn. (3).

(bs) Endoderm with thin onter walls. Resin candls 2 to 4 . . . . . . . . . . . . . . I' canaricusis simm (3).

(c) Endudem strangled-cocon like.

The space between the 2 fibro-vatular bundles rer wide. The sclerenchyma cells foming an irregular line betow the fibro-vacular bundles, occitsionally seteral of them are scattered alone the bundles. The seletenchyna cells surrounding the resin canals alwayt continuous at the part touching the hypoderm. Revin canals 2 to 15 , external, occasionaly with one on two mediat callats. Ilypdem consisting of onc layer of thin-walled cells, often having parts which consist of 2 layers of cells. . . . . . . . . . . P. siliestris $\mathrm{I}$. (2). 
Those species enclosed in parenthesis " $\{$. . . . . \}" in this Analytical Key (Chapter VJII), are either such as fail to show some distinct peculiarity, or which, because of possible slight changes in theit characters, are difficult of exact classification.

\section{LITERATURF, CITEN}

t. RFкTRAsn, C. F. : Anatomie comparée des tiges et des feuilles cliez les finétacées et les (Gniféres. Thèses préscntées a la faculté des Sciences de Paris prur nbtenir le grade de

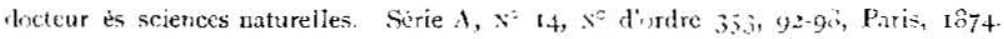

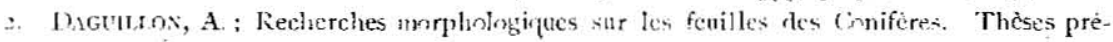

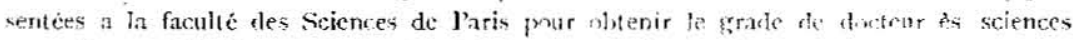

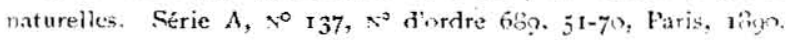

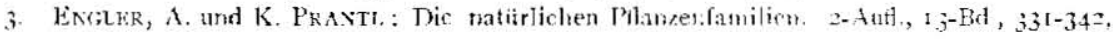
I_eipzig, 1926.

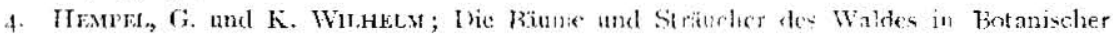
und Forstwirtchafticher Beyichung. Seit, $120-190$.

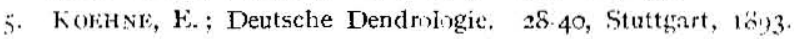

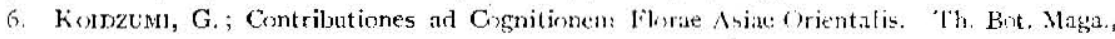
XXXVIII, 449, 113, 1924 .

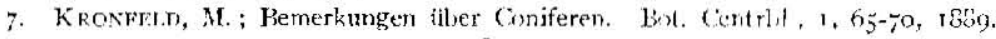

28. MAHLERT, A.; Reiträge zur Kennlviss der Anatonde der Laubblätter der Coniferen nit hesonderer Beriicksichtigung des Spaltöffnungs-ipparates. Jint. Centrhl., 24, 120-122, 149 $153,1 \% 3$.

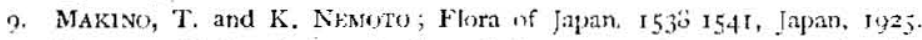

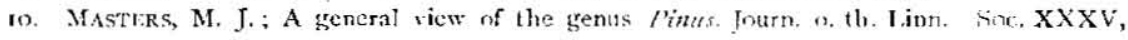
$24 \%, 560.659,1904$.

11. Morr, Ch. and I. Roth; The Timber Pines of the siouthern Inited States. Dissertation, Washington, 1696.

12. Mokrkaws, K.; Anatomische Intersuchungen iber die Vadeln der Zwischen-Formen un Pinus dtusiflora und P. Thunbergii. (Tapanisch nit Deutsche Zusammenfassung.), la Julteron Sciencit de la liakultato Terkultura, Kjuŝ Imperia Uniwersitato. Vol. z, No. 2, $96-113$, Japan, 1926.

13. Sraw, G. R, The Pines of Mexion. Disserlati in, Fush, Igon.

14. Siraw, G. R.; The Genus P'inus. Dissertation, Cambridgc, rgi4.

15. ZANG, W.; Die Anatomie der Kiefernadel und ihre Verwendung zur systematischen (ilicderung der Gattung fimt., I Dissertation, Giessen, rgo.

․ INDEX TO THE SPECIES, VARIETIES AND THELR SYYONYMS IN THE ANALYTICAY. KEV (CHAPTER VII.)

The scientific names of the admitted Species or

- Varieties are in roman type, of Synonyms in italics. 
Caryopitys edulis SMALI $=P$. edulis ENGELM.

Pinus abasica CARRlèkE $=P$. hatepensis MILLER

$P$. abcharica HoRT $=P$. halepensia MiLler

adunea $\mathrm{B} \cup \mathrm{SC}=P$. ratiata $\mathrm{D}$. DoN

alba-canadensis Provancher $=P$. strobus $\mathrm{L}$.

1. albicaulis ENGELM. $\ldots \begin{array}{lllllllllllll} & \ldots & \ldots & \ldots & \ldots & \ldots & \ldots & \ldots & \ldots & \ldots & \ldots & \ldots & 172\end{array}$

$P$ alepensis POIR $\mathrm{ET}=P$. Ialepensis MiLIER

alopecuroides HOR' $=P$. serotina MichauX

Altamirani SHAW $=P$. Lazusonii ROEZL

altissint $\alpha$ LEDEBOUR $=P$. silvest $r$ is $L$.

$\begin{array}{llllllllllllllll}\text { P. } & \text { amamiana Koldz. } & \ldots & \ldots & \ldots & \ldots & \ldots & \ldots & \ldots & \ldots & \ldots & \ldots & \ldots & \ldots & 170\end{array}$

P. Antoineana RoEZL $=P$. psezdostrobus LiNDi.

apacheca $\mathrm{LEMMON}=P$. ponderosa DOUGLAS

apulcensis LiNDL $=P$. pseadostrobus LiNDL.

anabica SIEBER $=P$. halepensis MHLER

aracanensis $\mathrm{KNIGHT}=P$. pinen $\mathrm{I}$.

artica $\mathrm{HoRT}=P$. pinea $\mathrm{L}$.

Argyi LEMÉ et LEVEHL $6=P$. tabulaeformis CARRTERE

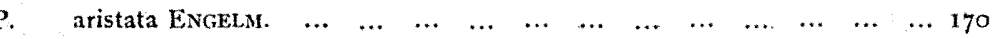

P, arizonica ENGELM. $\ldots \begin{array}{llllllllllll} & \ldots & \ldots & \ldots & \ldots & \ldots & \ldots & \ldots & \ldots & \ldots & \ldots & 178,181\end{array}$

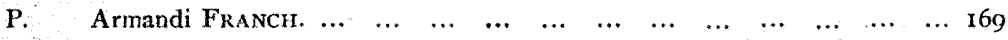

P. armena $\mathrm{KOCH}=P$. silvestris $\mathrm{L}$.

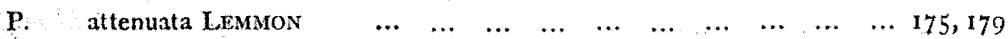

P. $\quad \begin{array}{lllllllllllll} & \text { ayacahuite EHRENBERG } & \ldots & \ldots & \ldots & \ldots & \ldots & \ldots & \ldots & \ldots & \ldots & \ldots & 170\end{array}$

$P$. Aucklandit LoDDIGES $=P$. Gentiana WAIL.

" australis $\mathrm{HOR} \mathrm{T}=P$. halepensis MILLFR

" australis MichauX $=P$. palustris MILleR

" austrica Höss = P. migra AR NOLD

" bahamensis Griserach $=P$, caribaea Morelet

" Balfouriana BALFOUR $=P$. Balfouriana MURRAY

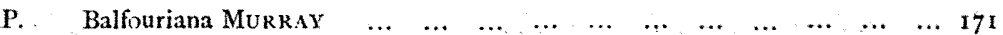

$P$. Balfouriana var. aristata ENGELM. $=P$. aristata ENGELM.

". Balfouriana WATS. $=P$. aristata ENGELM.

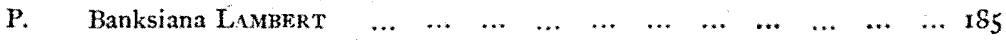

P. Banksiana LINDL. et GoRD. $=P$. contorta Dovglas

" Beardsleyi Murray $=P$. ponde tosa Douglas

$"$ Benthamiana HAR TWEG $=P$. ponderos $a$ Douglas

" Bessereriana RoFzL $=P$. teocote SCHLECHT, et CHAll.

" Bolander $i \mathrm{PARL}_{\mathrm{AR}}=P$. contort $i$ DOUGLAS

"Bonatatea RoEZt $=P$. ayacahute EHRENBERG

" borealis Salisturry $=P$. silvest $i$ is $\mathrm{L}$.

" Boursieri CARRIERE $=P$. contorta DOUGLAS

" lirachyptera ENGELM. $=P$. ponderosa Dovglas

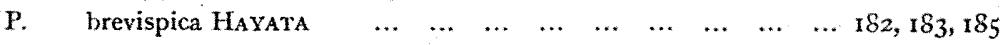

$P$. brutia TENORE $=P$. halepensis MILLER

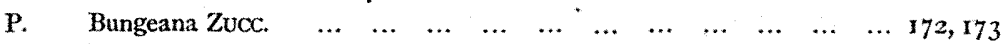

$P$. califortiana LOISELEUR $=P$. radiata $\mathrm{D}$. DON 
P. californica HARTWEG $=P$. attenuata LEMM. 
$P$. depiendens RoezL $=P$. leiophylla Schlecht. et Cham.

". detritis $\mathrm{HORT}=P$. pinaster SOLANDER

" Devoniana I INDL. $=P$. Montezumae I AMB.

, Dicksonii HoRT $=$ P. excelsa WALLICH

" divaricata DUMONT DE COURSET $=P$. Banksiana LAMBERT

$"$ domestica MaTTHews $=P$. pinea $\mathrm{L}$.

" Donnell-Smithii MASTERS=P. Montezumae var. Hartwegii EngElM.

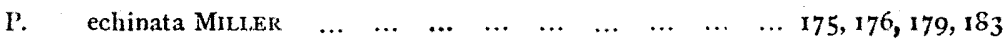

P. $\quad$ chinata HORT $=P$. montana MILLER

Edgariana $\mathrm{HARTWEG}=P$. matricati $\mathrm{D}$. DON

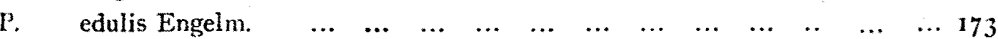

P. Ehrenberyii $\mathrm{ENDL}=P$. Montezumae var. rudis SHAw

" cldarica MEDWEjEw $=P$. halepensis MrLi.ER

" Elliotii ENGELM. $=P$. caribaea MoreleT

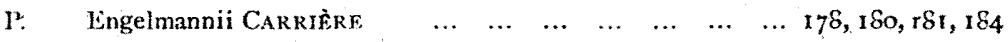

P. Escandoniana RoEzL $=P$. pseididostrobtıs I.1NDt.

$" \quad$ escarena $\mathrm{RISSO}=P$. pinaster SOLANDER

$" \quad$ excelsa BREIT $=P$. pezce Griseb.

$"$ excelsa HoOKER $=P$. peuce Griseb.

" excelsa var peuce BrISSNER $=P$. petuce Griseb

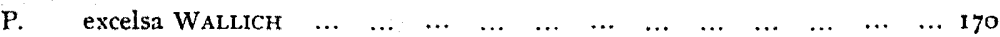

$P$. excorticata Lindu. et GoRD. $=F^{\prime}$. Bungeana ZuCC.

" fastuosa SALISBURY $=P$. pinea $\mathrm{I}$.

"Fenzlii ANTOINE et Korschy $=$ P. leiophyllir Schiecht. et CHAM.

" fertilis $\mathrm{ROEZL}=P$. cimbroides ZuCC.

$" \quad$ filifolia LINIL. $=P$. Montezuma LAMB.

" Finlaysoniana $\mathrm{W}_{\mathrm{ALLICH}}=P$. Merkusii JUNGH. et DE VRIESF

" Fischeri BOOTH $=$ P. montana MILLER

$" \quad$ Alexilis Balfour $=P$. albicaulis Engelm.

$\begin{array}{llllllllllllll}\text { P. flexilis James } & \ldots & \ldots & \ldots & \ldots & \ldots & \ldots & \ldots & \ldots & \ldots & \ldots & \ldots & \ldots & 172\end{array}$

P. Alexilis var, alticaulis, $\mathrm{ENGELM}=P$. albicaulis ENGELM.

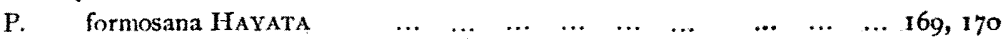

$P . \quad$ Fraseri L.ODDIGES $=P$. rigida MrLler

$" \quad$ Fremontiana ENDL. $=P$. monophylla TORREV

" Fremontiana GORDON $=P$. edulis ENGELM.

". Frieseana WichuR $\Lambda=P$. silvestris $\mathrm{I}$.

$\begin{array}{llllllllllll}\text { P. funebris KoMAROW } & \ldots & \ldots & \ldots & \ldots & \ldots & \ldots & \ldots & \ldots & \ldots & \ldots & \mathbf{1} 87, \mathbf{1} 88\end{array}$

$P$. futilis $\mathrm{SARGENT}=P$. cembroides $\mathrm{ZUCC}$. genevensis $\mathrm{HORT}=P$. silvestris $\mathbf{L}$.

genuensis $\mathrm{COOK}=P$. halepensis MuLER

georgica $\mathrm{HORT}=P$. palust ris MrLLER

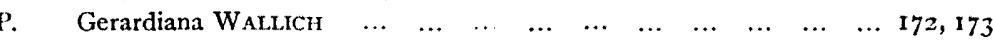

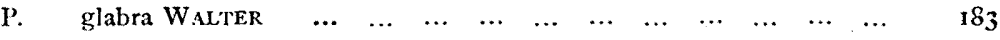

$P$. glomerata $\mathrm{SAlisbuRY}=P$. pinaster Solander

" Gordoniana HarTwiG $=P$. Montezumae LAMB.

, gracilis $\mathrm{ROEZL}=P$. leiophylla SChLECHT. et CHAM.

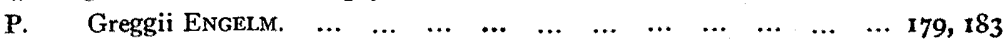


1. Grenvilleat GORD. $=P$. Montezzmiae LAMb.

Page

"Griffithii Mc Clelland $=P$. excelsa Wallich

" Grozelierii CAR RIÈRE $=P$. monticola Douglas

$" \quad$ haguenensis $\mathrm{LOUDON}=P$. silvestris $\mathrm{L}$.

" halepensis Bieberstein = P. nigra ArnoLd

$\begin{array}{lllllllllllll}\text { P. halepensis MLLLfR } & \ldots & \ldots & \ldots & \ldots & \ldots & \ldots & \ldots & \ldots & \ldots & \ldots & \ldots & 188\end{array}$

$P$. Hamiltonii TeNORE $=P$. pinaster SOlander

Hartwegrii LindL $=P$. Montezumae var. Hartwegrii $\mathrm{E}_{\mathrm{NGLF}}$

, Hartwegii PakL. $=P$. Monteztmae var. rudis SHaw

- Heldreichii Christ $=P$. leucodermis AntoIne

Henryi MASTERS $=P$. tabulaeformis CARrì̀R:

heteromorpha RoEzL $=P:$ pseudostrobus LIN1)L.

heterophylla SMALL $=P$. taeda $\mathrm{I}$.

heterophylla SUDwORTi $=P$. caribaca MoRELET

hierosolymitiana DUHAM, CL. $=P$. halepensis MuL.w

hispanica $\mathrm{COOK}=P$. halepensis MILLER

Hoseriana RoEzL= $P$. pseudostrobus LINDI.

hudsonia Porr. $=P$. Banksiana LAMBERT

huisquilca'nsis ROEzL $=P$. leiofhylla SCHLeCHT. et CHAM.

humilis $\mathrm{LINK}=P$. silvestris $\mathrm{I}$.

inops AITON $=P$. virginiana MILLER

inops BONGARD $=P$. contorta Dougl.AS

inops SOLANDER $=P$, virginiana MrLLER

inops war. clausa ENGELM. $=P$. clausa VASEY

insignis DOUGLAS $=P$. radiata $\mathrm{D}$. DON

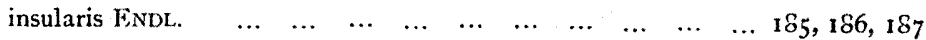

intermedia Fischer et Gordon $=P$. echinata MiLtek

japonica Forbes $=P$, densiflora Sifb. et ZucC.

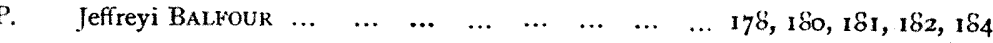

$P$. kasya ROYLE ex PARL $=P$. insular is ENDL.

khasia ENGELM. $=P$. insularis ENDL.

hhasyana GrIfFITH $=P$. insularis ENDL.

hhasyanus GRIFF. $=P$. insularis ENDL.

khasya ROYLE $=P$. insularis ENDL.

Kochiana $\mathrm{KLOTZSCH}=P$. silvestr is $\mathrm{L}$.

koraiensis MASTERS $=P$. Armandi Franch.

$\begin{array}{lllllllllllll}\text { P. } & \text { koraiensis Sieb. et ZuCc. } & \ldots & \ldots & \ldots & \ldots & \ldots & \ldots & \ldots & \ldots & \ldots & \ldots & 169\end{array}$

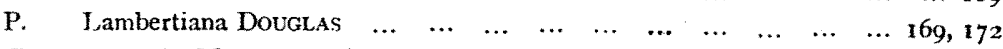

P. Iapponica $\mathrm{MAXR}=P$. silvestris $\mathrm{L}$.

, Laricio var. latisquama WILLKOMM $=P$. nigrn AkNOL.1

$" \quad$ Laricio var. leucodermis CHRIST $=P$. Leucodermis ANTOINE

" Taricio var. Poiretiana ANTOINE $=P$. nigra ARNOLn

" laricio $\mathrm{SAVI}=P$. pinaster SOLANDER

" latifolia SARGENT $=P$. ponderosa Douglas

" latisquama ENGELM.=P. Pinceana Gord.

" Latteri Mason $=P$. Merkusii Jungh. et DE VRIESE

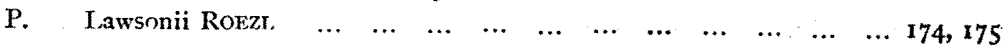


P. leiophylla BENTHAM $=P$. teocote SCHLECHT, et CHAM.

" leiophylla var. chihuahuana $\mathrm{SHAw} \doteq P$. chihuahuana ENGELM.

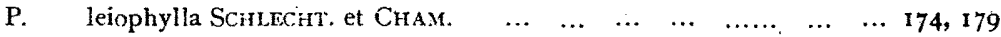

$P$. Lemonian BenthaM $=P$. pintster SOlander

" Leriloi RoEzL $=P$. leiophylla Scitlecht, et CHAM.

$\begin{array}{llllllllllllll}\text { P. } \quad l e u c n d e r m i s ~ A N T O I N E & \ldots & \ldots & \ldots & \ldots & \ldots & \ldots & \ldots & \ldots & \ldots & \ldots & \ldots & 182\end{array}$

$P$. leucosperma MAXIM. $=P$. tabztheformis CARRIERE levis I,EMÉE et I.EVELLLÉ $=$ I'. Armandi FRANCH. Jindleyana Gornon $=P$. Montezumae var. Lindleyi $\mathrm{I}$, ounoN Lilavenna SCinEDE $=P$. cembroides ZucC. Loddigesii I.OUDON $=l$. rigida MILLER

Loiseleztrian CARRIV̀R $=P$. halepensis MLLEK

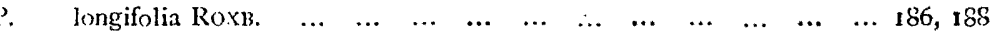

P. long ifolia SAlisbur $\mathrm{Y}=I^{\prime}$. Falustris MILLER Lophosperma I.INDL $=$ '. 'Torreyana PARRY Loudoniana $\mathrm{GOR} D O N=P$. ayacallate EHRENBERG

$\begin{array}{lllllllllllll}\text { P. luchuensis MAYR } & \ldots & \ldots & \ldots & \ldots & \ldots & \ldots & \ldots & \ldots & \ldots & \ldots & \ldots & \mathbf{1} \delta \mathbf{z}, 186\end{array}$

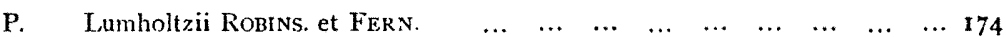

$P$. latea I ODnIGes et Goknon $=l$. echinati Milien latea $\mathrm{W}_{\text {ALTER }}=I^{\prime}$, taeda $\mathrm{L}$.

Macintoshiana HoR $\mathrm{Y}=I$. contorta DOUGLAS

macrocarpa LINDL. $=$ I'. Coulteri D. DON

macrophylla ENGELM $=P$. Engelmannii CARRIÉRE

macrophylla LiNDL. $=P$. Montezumize LAMB.

maderiensis $\mathrm{T}$ HNORE $=P$. pinea $\mathrm{L}$

mandschurica 1 , AwSON $=P$. pumila RFGEL

mandschurica RUPRECITT $=P$. korniensis SIFR. et ZUCC.

maritima ArTON $=? \cdot$ nigra AR NOLD

maritima I,AMARCK $=P$. pinaster SOLANDER

martima $\mathrm{I}$,AMB $=P$. halepensis MILLER

maritima MILLER $=P$. pinaster SOLANDEk

maritima $\mathrm{POI \textrm {K }} .=P$. pinaster SOLANDER

Massoniana $\mathrm{HORT}=P$. densifor $a$ SifB. et ZuCC.

$\begin{array}{lllllllllllll}\text { P. Massoniana LAMBERT } & \ldots & \ldots & \ldots & \ldots & \ldots & \ldots & \ldots & \ldots & \ldots & \ldots & \ldots & 187\end{array}$

F. Metssoniana SikB. et ZuCC. =P. Thunbergii PARI.

Maste $r$ sian $a$ HaYaTa $=P$. Armaniti Franch.

May $\cdot$ iana Sudvortir $=P$. ponderosa Douglas

Merkiaan Gordon $=P$. Merkusii JUNGH. et DF VRIfse,

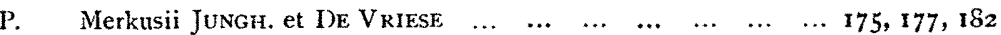

$P$. microcarpa RoezL $=P$. teocote SCHLECHT. et Cham.

minor IIORT $=P$. haleponsis MILLER

mitis MichauX $=P$. echinata MrLler

monophylla alar, edulis M. E. JONES $=P$ eduitis ENGELM.

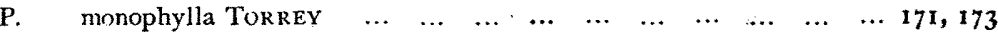

$P$. monspeliensis SaltzMAN $=P$. pinaster SOlanek

montana LAMARCK $=P$. cembra $\mathrm{L}$.

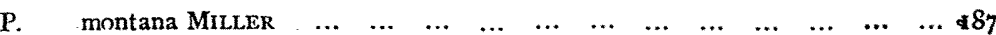


P. montana NOLL $=P$. prungens LAMBERT

" Monte-Allegri RofzL $=P$. leiophy lla Schlecht. et Cham.

$" \quad$ montereyensis RAUCH $=P$. mainta $\mathrm{D}$. DON

". Montezumae GoknON=P. Nontezumee var: rudis SHaW

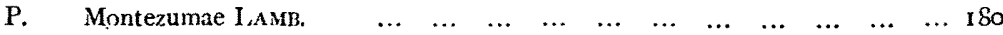

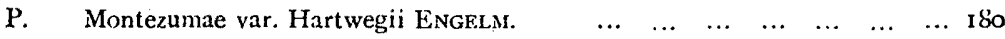

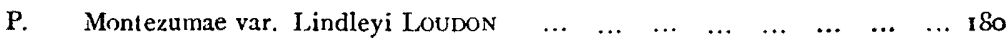

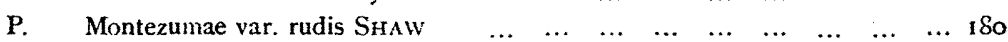

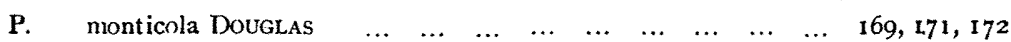

r. morrisonicola HAYATA $=P$. formosani HAYATA

" Muelleriana RoEzL $=P$. teocote SChlecht. et Cham.

" mugho POIRET $=P$. montana MrLlER

$" \quad$ mughus JACQUIN $=P$. silvestr is $\mathrm{L}$

$" \quad$ mughus SCOPOLI $=P$. montana MILLER

" muricata BOLANDER $=P$. contorta DOUglas

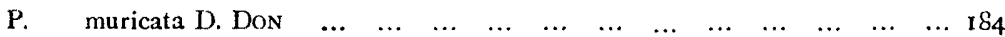

P. Murrayana BALFoUR $=l$. contorta Douglas

$" \quad$ nana FAURIE et LEMÉE $=P$. tabulaeformis CAR RIEkE

$" \quad$ neglecta Low $=P$. pinaster SOLANDER

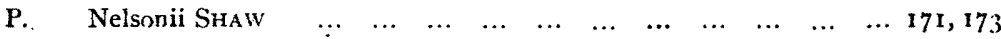

P. Neosa Chilgoza $=$ l'. Gerardiana Wall

nepalensis DE ChambRAY $=P$. excelsa Wallich

nepalensis ROVLE $=I$. pinaster SOLANDER

$\begin{array}{lllllllllllllll}\text { P. } & \text { nigra ARNOLD } & \ldots & \ldots & \ldots & \ldots & \ldots & \ldots & \ldots & \ldots & \ldots & \ldots & \ldots & \ldots & \text { I } 83\end{array}$

P. nigricans $\mathrm{HOST}=P$. nigra ARNOLI

" niz'ea BOOTH ex CARRIÊRE $=P$. strobus I,

$" \quad$ nivea HorT $=P$. monticoln DOLGLAS

$" \quad$ nootkatensis MANET'I $=r$. ponderosa Dovglas

$" \quad$ Nova-hollandica L ODDIGES $=P$. pinaster SOLANDER

$" \quad$ Nova-zelandica I.ODDIGES $=P$. pinaster SOLANDER

$"$ obliqua SAUTER $=P$. montama MILleR

" occidentalis HumbolnT $=P$ : Montezumae LAMB.

$\begin{array}{llllllllllllll}\text { P. } & \text { occidentalis SwarTt } & \ldots & \ldots & \ldots & \ldots & \ldots & \ldots & \ldots & \ldots & \ldots & \ldots & \ldots & 174\end{array}$

P.

$P$. oocarpoides LINDLEY $=P$. oocarpa SCHEDE

$" \quad$ orizabae GoRD. $=P$. psezrdostrobus LINDL.

$" \quad$ osteosperma ENGELM. $=P$. cembroides ZucCak.

" Pallasiana LAMB. $=P$. migra ArNoLr

$" \quad$ Palmieri MANETPI $=P$. palust,is MLLLR

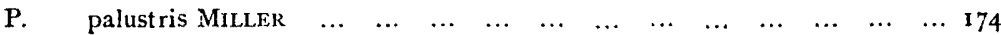

P. Paroliniann $\mathrm{WEBB}=P$. Aralepensis MILLEk

"Parolinii VIsLANI $=l$ '. Malepensis MILLER

$"$ Parryana ENGFLM = P. qual rifolia SUDworti

" Parryana GondoN $=P$. ponderosa Douglas

" parvifiora $\mathrm{HORT}=P$. parviflora SIEB. et ZUCC.

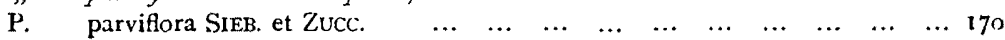

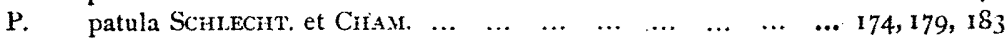

P. patuli SEEMANN $=P$. Lumholtziz ROBINSON et FERN. 
P. patula aar macrocarpa MASTERS = P. Greggiz ENGELM.

$"$ patula var. stricta BeNTHAM $=P$. Greggii ENGLM.

, a peninsularis LFMMON $=P$, ponderosa DOUgLas

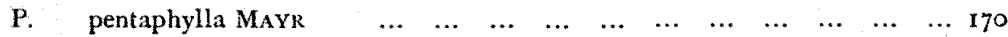

$P$. persica Strangways $=P$. halepensis Miller

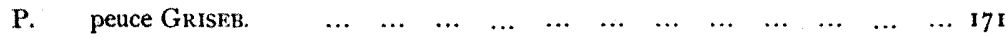

$P$. pinaster BESSER $=P$. nigm ARNOLD

" pinaster LoudoN $=$ P. Thunbergii PARL.

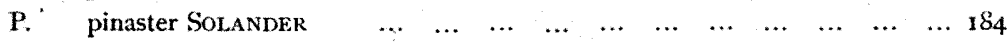

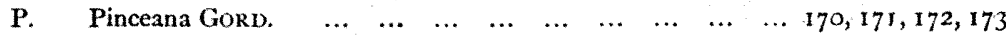

$P$. findica ForMANRK $=P$. leucolermis ANTOINE

$"$ finea GORDON $=P$. densiftora Sreb. et ZUCC.

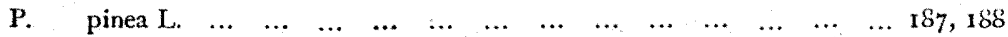

P. Pityusa Steven $=P$. halepensis MILlek

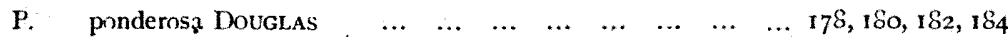

:P. fonderosa var. arizonica SHAW $=P$. arizonica ENGrLM.

$"$ fonderosa zar. Jeffreyi ENGELM. $=P$. Jeffrey $i$ BALFour

" Ponderosa var. macrophylla $\mathrm{SHAW}=P$. Engelmannii CARRIÈRE

"pontica $\mathrm{KOCH}=P$. silvestris $\mathrm{L}$.

" porphyrocarpa LAwSON $=P$. monticolin DOUGLAS

, prasina RoEZL $=$ P. pseudostrolnts I.INDL.

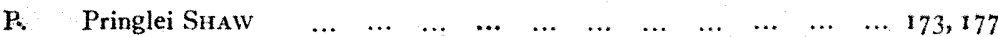

P. prominens MASTERS $=P$. tabnilaeformis $\mathrm{CARRIERF}$

" frotuberans ROEZL $=P$. fsewtostrobus LINDL.

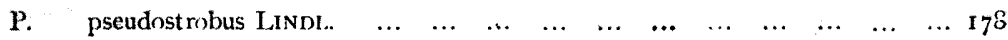

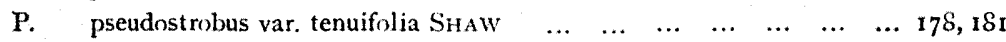

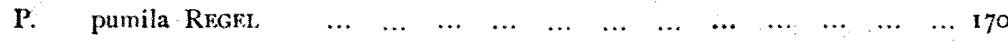

P. pumilio HaEnke $=P$. montona Mrller

$\begin{array}{llccccccccccc}\text { P. } & \text { pungens I.AMBERT } & \ldots & \ldots & \ldots & \ldots & \ldots & \ldots & \ldots & \ldots & \ldots & \ldots & 176,184 \\ P . & \text { pygmala } \text { Fischer }=P . \text { pumila } & \text { REGEL } & & & & & & & & \end{array}$

" Pyrchaica DAVID $=P$. halepensis MILLER

" fyrenaica L.APEYROUSE $=P$. migra ARNoID

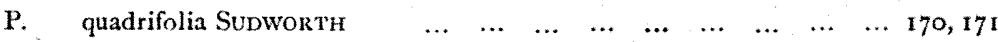

P. quinquefoliz $\mathrm{DAvDD}=P$. Armandi $\mathrm{FRANCH}$.

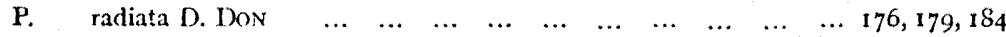

$l$ r. radiata HoOKER et ARNOTT $=P$. Montezumate I.AMB

$" \quad$ recurvata RowLEY $=P$. caribaea MORELET

reflexa ENGELM. $=P$. Alexilis JAMEs

Regeliana ROEZL $=P$. pseadostrobus LINDL.

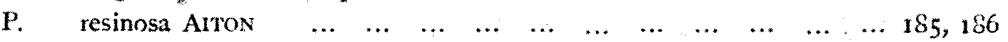

P. resinosa LOISELEUR $=P$ : " halepensis MILLFR

" resinosa $\mathrm{SAVI}=P$. siliestris $\mathrm{I}$.

" resinosa TORREY $=P$. pondernsa DOUGLAS

, rigrensis DESFONTAINFS $=P$. siliestris $\mathrm{I}$,

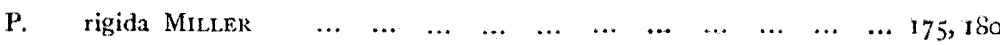

P. rigida PORCHeR $=P$. echinata MLlLek

" rostrata $\mathrm{HOR} \mathrm{T}=P$. montana MuLER 
P. Roxburghii SARGENT $=P$. longifolin RoxB. 
P. $\quad$ sylzastris MILLER $=P$. pinaster SOLANDER

" sylvestris THUNB. $=P$. Thunbergii PARL.

" sy'tica $\mathrm{THORE}=\mathrm{P}$. pinaster SOLANDER

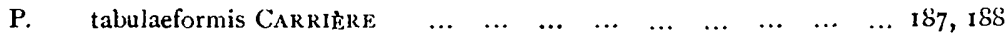

$P$. $\quad$ taeda BLANCO $=P$. insular is ENDL.

" taeda var. echinata CASTIGLIONI $=P$. echinata MILLER

" taeda var. heterophylla ELLIOTT $=$ P.caribaea MORELE'T

" taed $a$ LAMBER'T $=P$ : pringens I.AMBERT

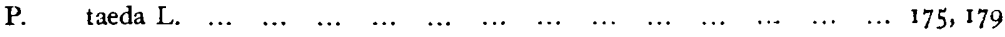

P. taeda var. variabilis AlTON $=P$. echinata MHILER

$\begin{array}{llllllllllll}P . & \text { taiwanensis HAYATA } & \ldots & \ldots & \ldots & \ldots & \ldots & \ldots & \ldots & \ldots & \ldots & 182,183,185\end{array}$

$P$. tamrac MURRAY $=P$. contorta Douglas

" tatarica $\mathrm{HORT}=P$. halepensis MILLER

" taturica MHLER $=P$. silvestris $\mathrm{I}$.

" toxifolia LAMBERT $=P$. pseudostrobus IINDL.

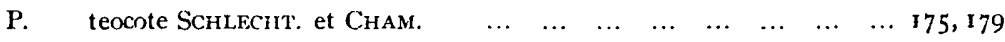

P. tenuifolia BenthaM $=P$. psezdostrobus zar tenuifolia SHaw

temifolia SALISBURY $=P$. strobns $\mathrm{L}$.

tenuis LEMMON $=P$. contorta Douglas

terthrocarpa SHAW $=P$. tropicalis MORELE'I

$\begin{array}{lllllllllllllll} & \text { P. Thunbergii PARL. } & \ldots & \ldots & \ldots & \ldots & \ldots & \ldots & \ldots & \ldots & \ldots & \ldots & \ldots & \ldots & 183\end{array}$

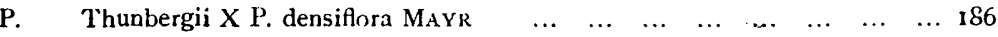

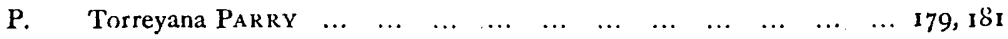

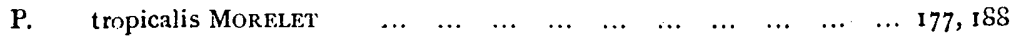

P. tuberculata D. DON $=P$. radiata D. DON

tuberculata GORDON $=P$. attenuata LEMM.

Tzomfoliana ROEZL $=P$. pseatlostrobas LINDL.

uliginosa NeumanN $=P$. montana Miller.

umbraculifera HORT $=P$. strobus $\mathrm{L}$.

uncinata RAMONI $=P$. mont 1 na MILLER

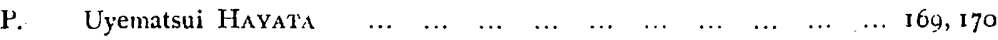

P. $\quad$ zariabilis LAMBERT $=P$. echinata MiLLER

z'ar iatbilis var. echinata $\mathrm{DU}$ ROI $=P$. echinata MILLER

l'aitchii RoEZL $=P$, ay'acahuite EHRFNBERG

iermicularis JANKA $=P$. peuce (iRISEB.

zerrucosa RoEzL $=P$. leiophylla SCHLECHT. el ChaH.

Vilmoriniana RorzI $=P$. teocote SchifchT. et Cham.

$\begin{array}{lllllllllllll}\text { virginiana MILLLR } & \ldots & \ldots & \ldots & \ldots & \ldots & \ldots & \ldots & \ldots & \ldots & \ldots & \ldots & 176,183\end{array}$

airginiona alar: echinata DU ROI $=I$ '. echinata MILLEK

Wilsonii SHAW $=$ P. tabulaeformis CARRIERE

Wincesteriana GoRDON $=P$. Montezmale LAMB.

Wrightii FNGEI.M. $=P$. occidentaits SwARTz

yunnanensis FRANCHET $=P$. tabulaeformis CARRIŚRF

Strobus strobus SMALLFI'. strobus $\mathrm{L}$.

From the Silvicultural Institute, Department of Agriculture, Kyushu Imperial University. January, I92y. 